INTERNATIONAL MONETARY FUND

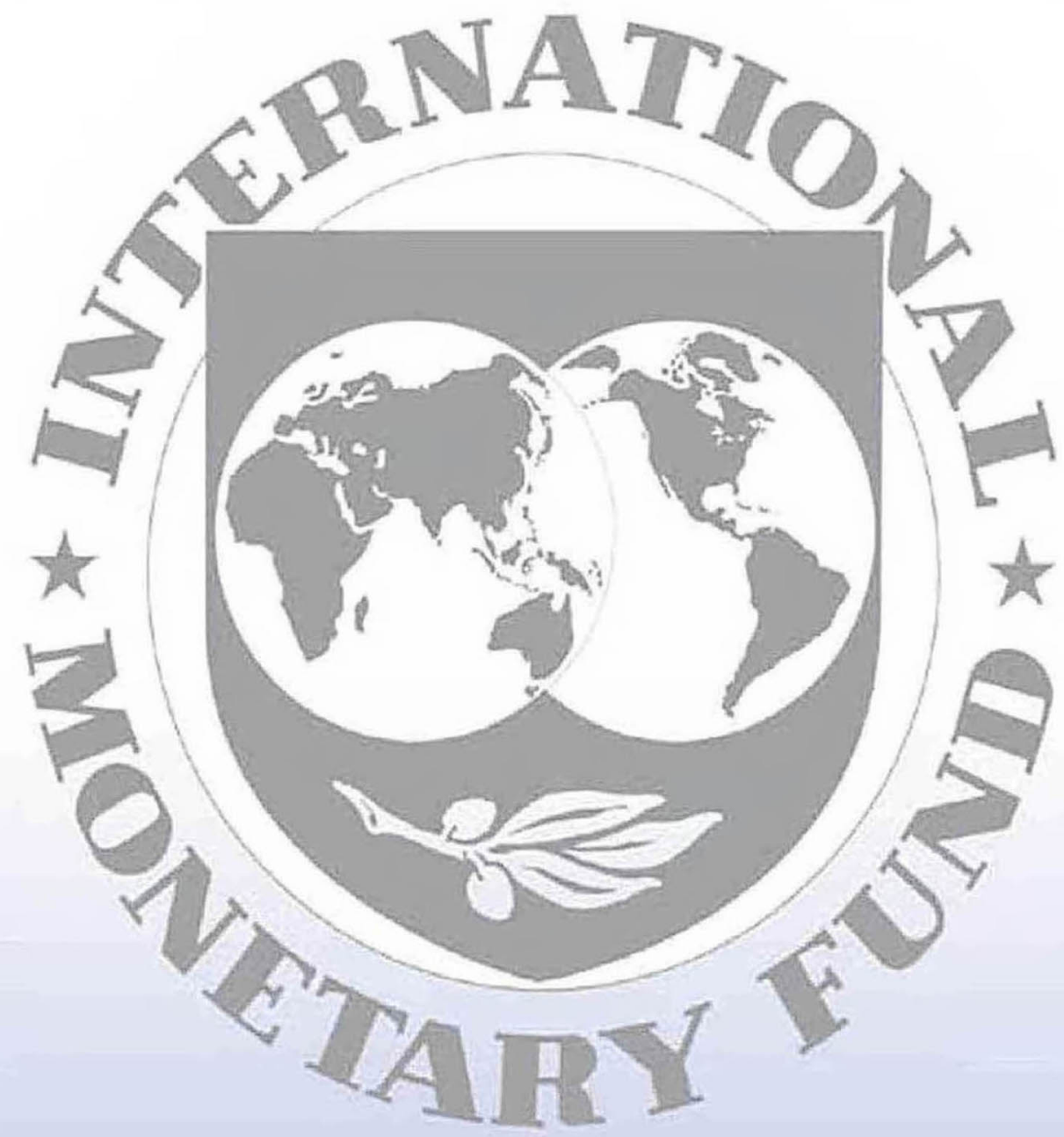

Staff

Country

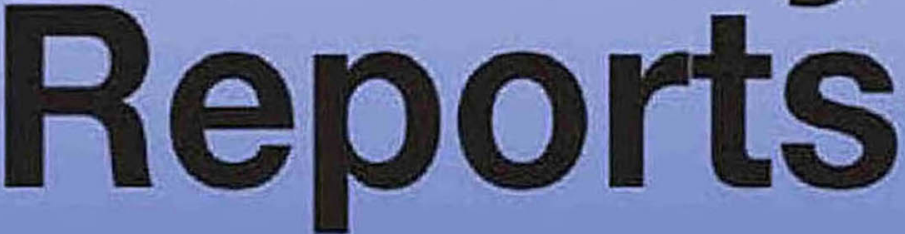




\section{Greece: Ex Post Evaluation of Exceptional Access under the 2010 Stand-By Arrangement}

This ex post evaluation of exceptional access under the 2010 stand-by arrangement on Greece was prepared by a staff team of the International Monetary Fund. It is based on the information available at the time it was completed on May 20, 2013. The views expressed in this document are those of the staff team and do not necessarily reflect the views of the government of Greece or the Executive Board of the IMF.

The policy of publication of staff reports and other documents by the IMF allows for the deletion of market-sensitive information.

Copies of this report are available to the public from

International Monetary Fund $\bullet$ Publication Services

$70019^{\text {th }}$ Street, N.W. • Washington, D.C. 20431

Telephone: (202) 623-7430 • Telefax: (202) 623-7201

E-mail: publications@imf.org Internet: http://www.imf.org

Price: $\$ 18.00$ a copy

\section{International Monetary Fund \\ Washington, D.C.}




\section{INTERNATIONAL MONETARY FUND}

\section{GREECE}

\section{EX POST EVALUATION OF EXCEPTIONAL ACCESS UNDER THE 2010 STAND-BY ARRANGEMENT}

\section{EXECUTIVE SUMMARY}

The primary objective of Greece's May 2010 program supported by a Stand-By Arrangement (SBA) was to restore market confidence and lay the foundations for sound medium-term growth through strong and sustained fiscal consolidation and deep structural reforms, while safeguarding financial sector stability and reducing the risk of international systemic spillovers. Greece was to stay in the euro area and an estimated 20-30 percent competitiveness gap would be addressed through wage adjustment and productivity gains.

There were notable successes during the SBA-supported program (May 2010-March 2012). Strong fiscal consolidation was achieved and the pension system was put on a viable footing. Greece remained in the euro area, which was its stated political preference. Spillovers that might have had a severe effect on the global economy were relatively well-contained, aided by multilateral efforts to build firewalls.

However, there were also notable failures. Market confidence was not restored, the banking system lost 30 percent of its deposits, and the economy encountered a muchdeeper-than-expected recession with exceptionally high unemployment. Public debt remained too high and eventually had to be restructured, with collateral damage for bank balance sheets that were also weakened by the recession. Competitiveness improved somewhat on the back of falling wages, but structural reforms stalled and productivity gains proved elusive.

Given the danger of contagion, the report judges the program to have been a necessity, even though the Fund had misgivings about debt sustainability. There was, however, a tension between the need to support Greece and the concern that debt was not sustainable with high probability (a condition for exceptional access). In response, the exceptional access criterion was amended to lower the bar for debt sustainability in systemic cases. The baseline still showed debt to be sustainable, as is required for all Fund programs. In the event, macro outcomes were far below the 
baseline and while some of this was due to exogenous factors, the baseline macro projections can also be criticized for being too optimistic.

The report considers the broad thrust of policies under the program to have been appropriate. Rapid fiscal adjustment was unavoidable given that the Greece had lost market access and official financing was as large as politically feasible. Competivenessboosting measures were also essential, as were fiscal structural reforms to support deficit reduction. However, the depth of ownership of the program and the capacity to implement structural reforms were overestimated.

Greece's SBA suggests the need to explore the case for refining the Fund's lending policies and framework to better accommodate the circumstances of monetary unions. A particular challenge is to find ways to translate promises of conditional assistance from partner countries into formal program agreements.

There are also political economy lessons to be learned. Greece's recent experience demonstrates the importance of spreading the burden of adjustment across different strata of society in order to build support for a program. The obstacles encountered in implementing reforms also illustrate the critical importance of ownership of a program, a lesson that is common to the findings of many previous EPEs.

Other lessons drawn concern the need to find ways to streamline the Troika process in the future and for Fund staff to be more skeptical about official data during regular surveillance. The detailed nature of the structural fiscal conditionality in the Greek program also bears scrutiny given the premium attached to parsimony in Fund conditionality. 
Authorized for distribution by the European

Department and the Strategy, Policy, and

Review Department
Prepared by an interdepartmental staff team consisting of J. Gordon (head, OBP), I. Karpowicz (OBP), S. Lanau (SPR), J. Manning (EUR), W. McGrew (EUR), M. Nozaki (FAD), and M. Shamloo (EUR), with assistance from A. Shtuni (OBP) and C. Piatakovas (EUR).

\section{CONTENTS}

BACKGROUND TO THE CRISIS

A. The build-up of imbalances __ $\underline{5}$

B. Crisis triggers _

C. Crisis response _ $\underline{7}$

AN EXCEPTIONAL FUND PROGRAM __ $\underline{\mathbf{9}}$

PROGRAM STRATEGY AND IMPLEMENTATION __ $\underline{\mathbf{1 0}}$

PROGRAM OUTCOMES _ $\underline{\underline{12}}$

A. Macroeconomic outcomes _ $\underline{12}$

B. Fiscal policy outcomes__ 14

C. Debt and financing outcomes__ 16

D. Structural reforms__ 18

E. Financial sector _ 18

PROGRAM DESIGN __ $\underline{\mathbf{2 0}}$

A. Should the fiscal adjustment path have been more gradual? __ $\underline{20}$

B. Should the adjustment path have been more flexible? __ 21

C. Should the larger economic downturn have been expected? __ 21

D. Were structural reforms sufficient to restore competitiveness and growth? __ 22

E. Was the mix of fiscal measures appropriate? __ $\underline{23}$

F. Was there sufficient ownership and capacity for reforms?__ $\underline{24}$

G. Was the financing of the program likely to be sufficient? __ $\underline{25}$

$\mathrm{H}$. Should debt restructuring have been attempted at the outset? __ $\underline{26}$

CONSISTENCY WITH FUND RULES AND PRACTICES __ $\underline{\mathbf{2 9}}$

A. Was exceptional access justified? __ $\underline{29}$

B. Was the SBA consistent with other Fund programs with countries in currency unions?___ 
C. How well did the Troika arrangement work? $\underline{31}$

D. Should the EFF have been introduced at the beginning? $\underline{31}$

\section{BOXES}

1. A Chronology of Events $\underline{35}$

2. Progress with Internal Devaluation under the SBA-Supported Program $\underline{36}$

3. Pension Reform $\underline{38}$

4. Revenue Administration Reform during the SBA-Supported Program $\underline{39}$

5. Structural Benchmarks: Design and Implementation 41

\section{TABLES}

1. Selected Economic Indicators, 2009-14 $\underline{42}$

2. Quantitative Performance Criteria, 2010-13 43

3. Structural Conditionality 44

REFERENCES

References 47

\section{APPENDIX}

I. Views of the Authorities 


\section{An Ex-Post Evaluation (EPE) of Exceptional Access under Greece's 2010 Stand-By}

Arrangement (SBA) is timely. The Fund's rules require an EPE of exceptional access decisions within a year of the arrangement ending. This requirement is intended to ensure uniformity of treatment across members and that no large program escapes evaluation. Greece's SBAsupported program, approved in May 2010 and cancelled in March 2012, was an exceptionally large program with access of $€ 30$ billion and warrants evaluation even though the SBA was immediately succeeded by an extended arrangement under the Extended Fund Facility (EFF). As with all EPEs, the purpose of the report is (i) to review performance against program objectives; and (ii) to evaluate program design encompassing the macroeconomic strategy, program architecture, adequacy of financing, and the case made for exceptional access.

\section{BACKGROUND TO THE CRISIS}

\section{A. The build-up of imbalances}

2. Euro accession led to an economic boom in Greece. Adoption of the euro and loose global credit conditions in the 2000s allowed Greece easy access to foreign borrowing that financed a significant expansion of government spending. Robust private credit growth following financial liberalization also served to boost household consumption. Real GDP growth averaged 4 percent from 2000-07, higher than in all euro area countries save Ireland and Luxembourg. Although asset price inflation and household indebtedness remained moderate, government debt mounted rapidly.

3. Fiscal policy was pro-cyclical. Some argue that Greece was the country that gained most from euro adoption (Fernandez-Villaverde et al, 2013) with borrowing costs falling sharply. As a direct fiscal dividend, government interest expenditure dropped

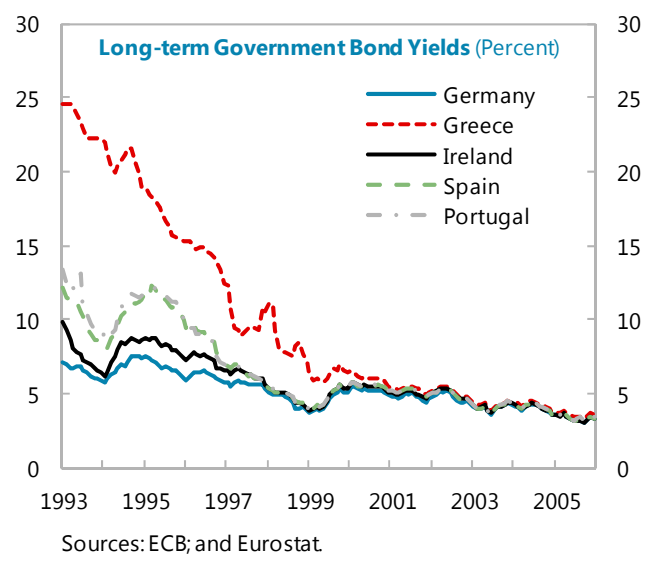
from $11 \frac{1}{2}$ percent of GDP in the mid-1990s to 5 percent of GDP in the mid-2000s. However, these savings were more than swallowed up by increased spending on wages and pensions. The economy turned down in the wake of the Lehman crisis and the general government deficit reached 151/2 percent of GDP (after incorporating data revisions), up from 4 percent of GDP in 2001. Public debt was 129 percent of GDP at end-2009, with 75 percent held by foreigners. There were also significant contingent liabilities due to public enterprises borrowing under state guarantee, while the pension system had become underfunded as a result of increasingly generous entitlements and an aging population. 

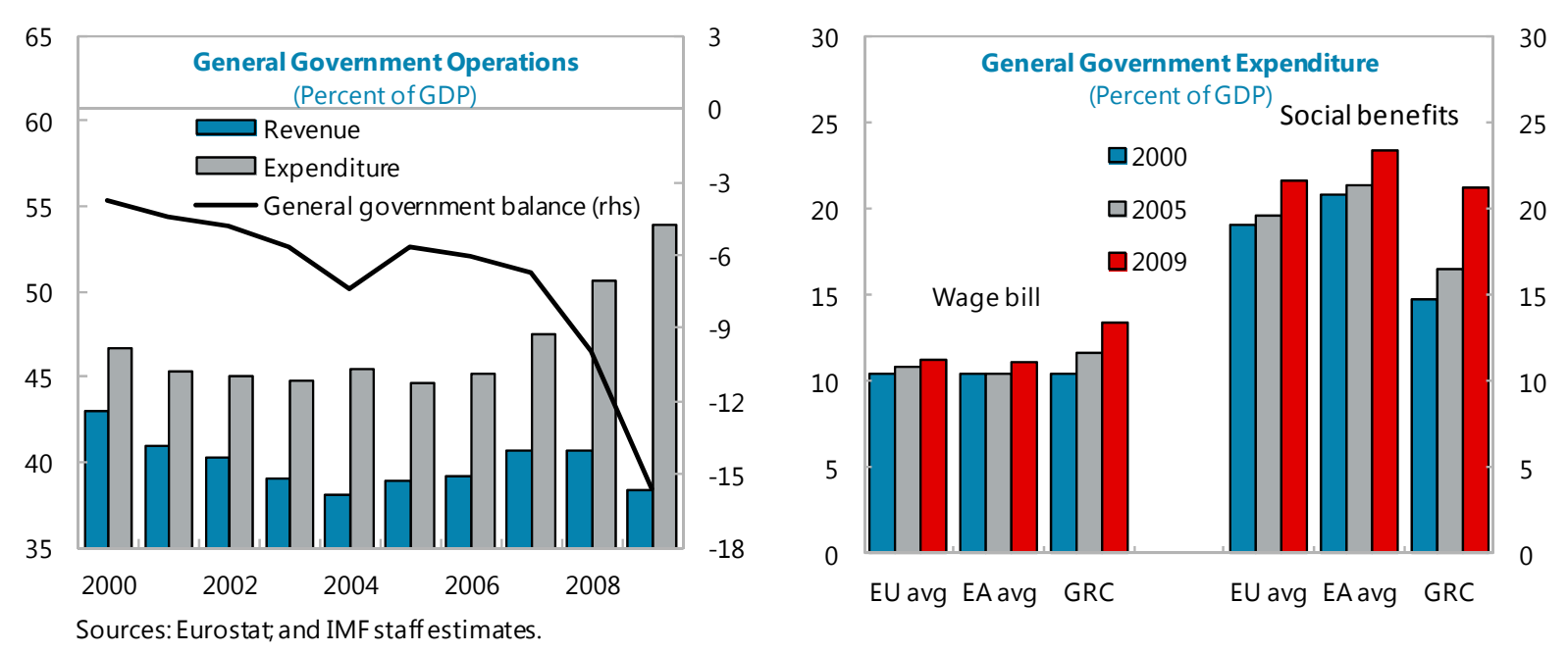

4. The current account deficit deteriorated. The counterpart to the decline in government saving was a sharply widening current account deficit that reached 15 percent of GDP in 2008. The sustained economic boom and a lack of competition in domestic goods and services markets kept wage and price inflation consistently above euro averages. Competitiveness, as measured by the unit labor cost (ULC) -based real effective exchange rate (REER), declined by 20-30 percent in the decade following euro adoption.

\section{There were also serious doubts about} the quality of Greek deficit and debt

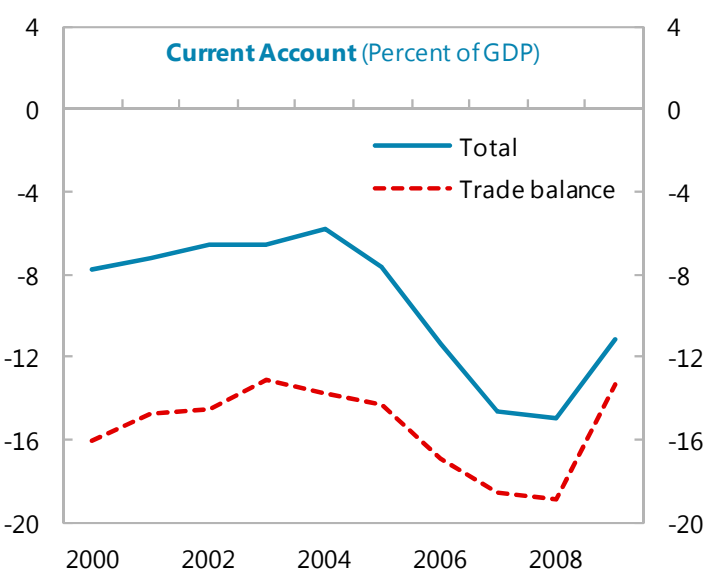

Sources: Bank of Greece; Elstat; and IMF staff calculations. statistics. Data concerns had flared up in 2004 when upward revisions to the fiscal deficit numbers raised questions about whether Greece had ever met the Maastricht deficit criterion of an annual fiscal deficit of 3 percent of GDP. The European Commission (EC) attempted to coax Greece into reducing its deficit via the Excessive Deficit Procedure of the Stability and Growth Pact.

\section{B. Crisis triggers}

6. The global financial crisis endangered Greece's government-led growth model. Greece's economic boom was propelled by large foreign-funded fiscal deficits that enabled demand to outpace output. The global crisis threatened the continued financing of this growth model. After the Lehman shock in September 2008, spreads on Greek government bonds over 10-year bunds jumped to 300 bps compared to about 50 bps before the crisis. Standard and Poor's downgraded Greece from A+ to A in January 2009 citing a loss of competitiveness worsened by the global financial crisis. Against this backdrop, Greece had become extremely vulnerable to a stop in private capital flows. 
7. Data revisions unsettled markets. In October 2009, a new government took office and announced that the fiscal problem had been significantly understated. The projected budget deficit for 2009 was revised up from 4 to 121/2 percent of GDP (still 3 percentage points short of the final estimate). Public debt estimates were also marked up sharply. Fitch responded by downgrading Greece's sovereign rating from A- to BBB+. Global markets, already roiled by events in Dubai in November 2009, sold off further. Scrutiny of Greek high sovereign indebtedness was extended to other euro area countries.

\section{Crisis response}

8. Initially, the authorities sought a European solution. In December 2009, Greece committed to achieving fiscal consolidation via a Stability Program with the EC. At the same time, the Greek authorities ruled out the possibility of seeking Fund help. The euro area authorities seemed of like mind, indicating that financial assistance from the Fund was not "appropriate or welcome" (see Mackenzie, 2010). Nonetheless, the new government recognized that tax administration and expenditure management were extremely weak and sought technical advice from the Fund. Missions that visited Athens in early 2010 provided initial roadmaps for fiscal structural reforms.

9. Greece agreed to a fiscal consolidation plan with the EC. Greece's 2010 Stability Program submitted to the EC in January 2010 aimed to cut the deficit from $121 / 2$ percent of GDP to 83/4 percent of GDP in 2010 and by a further 3 percentage points in 2011 and in 2012 (the "43-3" plan). To begin the process, the authorities announced the freezing of public sector wages, partial cancellation of civil servant bonuses, and increases in indirect taxes.

10. Markets, however, doubted whether these steps would be adequate. Financing conditions became progressively more difficult. Greece was able to raise $€ 5$ billion on two occasions in March 2010 at spreads of about 300 bps, but by the second issue, the foreign bid had dropped off appreciably. Spreads in the secondary market rose further in April, while large amortizations were coming due in May.

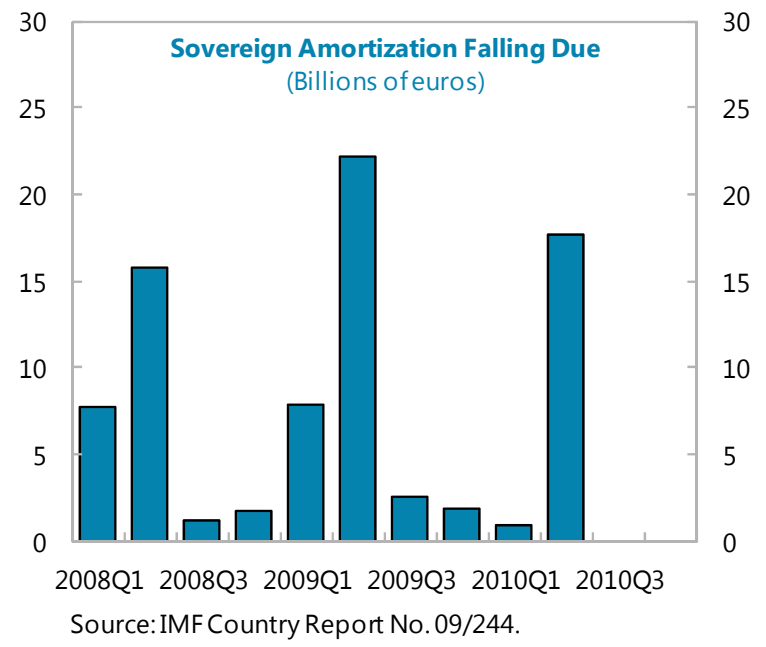


11. Against this backdrop, a request for a Fund program was made. The euro zone decided in April 2010 that the Fund should be a formal part of Greece's rescue. Following negotiations with the newly-established Troika (the Fund, the EC and the European Central Bank $(E C B)$ ), agreement on a program to assist Greece was reached in early May. Total financing was $€ 110$ billion, of which the Fund committed $€ 30$ billion under an SBA (approved May 9). The remainder of the financing took the form of bilateral loans from euro area countries to be pooled by the EC under the Greek Loan Facility.

12. The process of building a firewall began. Contagion from Greece was a major concern for euro area members given the considerable exposure of their banks to the sovereign debt of the euro area periphery. ${ }^{1}$ To prevent the crisis spilling over, the euro area initiated the creation of a financial safety net for its member countries. In early May 2010, agreement was reached to set up the European Financial Stability Facility (EFSF) with $€ 500$ billion in financing. ${ }^{2}$ Euro area and Fund officials confirmed that these resources could be supplemented by an additional $€ 250$ billion in lending from the Fund provided on a country by country basis.

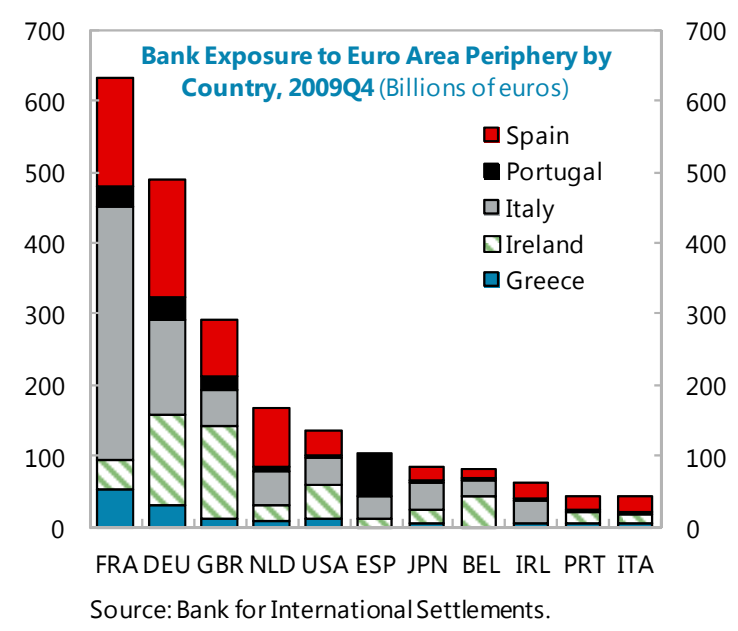

13. Additional assistance came from the ECB. The ECB's contribution was to set up the Securities Markets Program (SMP) in May 2010 that would purchase public debt securities in secondary markets. The ECB also relaxed its eligibility requirements so that Greek government debt instruments remained eligible as collateral for central bank financing despite now being below investment grade.

\footnotetext{
${ }^{1}$ The ECB argued that the financial integration associated with monetary union - a benefit during normal times served to intensify systemic spillover effects during periods of stress. See ECB (2011).

${ }^{2}$ The EFSF was incorporated as a company in Luxembourg on June 7, 2010 with a lending capacity of €440 billion that would be combined with loans from the European Financial Stabilization Mechanism (EFSM) of $€ 60$ billion. The EFSF was created as a temporary rescue mechanism; in December 2010, a decision to create a permanent crisis resolution mechanism, the European Stabilization Mechanism (ESM), was announced.
} 


\section{AN EXCEPTIONAL FUND PROGRAM}

\section{Greece's SBA-supported program was exceptional for a number of reasons:}

- Access was the largest in Fund history. Despite representing less than 30 percent of the financing, Fund access was $€ 30$ billion, or 3,212 percent of quota. This was the largest Fund program ever relative to quota.
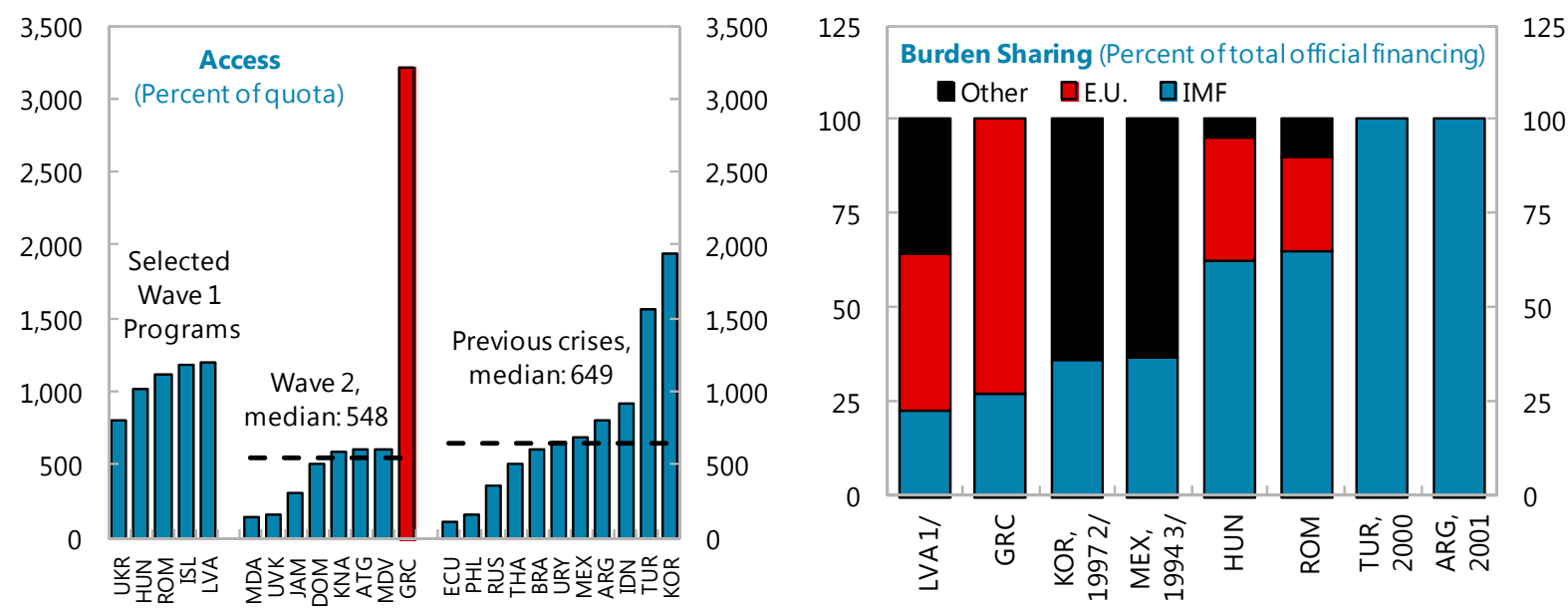

Sources: IMF country reports; and IMF staff estimates.

1/ Other includes $€ 3.1$ billion from EU, $€ 1.8$ billion from Nordic Countries, $€ 0.4$ billion from CZE, POL, and EST, and $€ 0.5$ billion from WB and EBRD.

2/ Other includes $\$ 5$ billion from U.S., $\$ 10$ billion from each WB and BoJ, $\$ 4$ billion from ADB, and the rest from other $\mathrm{G} 7$.

3 / Other includes $\$ 20$ billion from U.S., $\$ 10$ billion from BIS and $\$ 1$ billion from Bank of Canada.

- It was the first ever program with a member of the euro area. A Fund program supporting a member that had fixed its exchange rate was not unprecedented (for example, Latvia), nor was a program with a continuing member of a currency union (recent examples are St. Kitts, Benin, and Burkina Faso). Greece stood out because it is a euro area member and the euro is a reserve currency.

- The Troika set up was novel. The Fund had recently joined forces with the EC in programs with EU members outside the euro area (Hungary, Latvia, and Romania). However, Greece was the first program in which the ECB was formally involved.

- Public debt would remain exceptionally high during the program period. Despite a large fiscal adjustment, public debt was expected to keep rising during the program

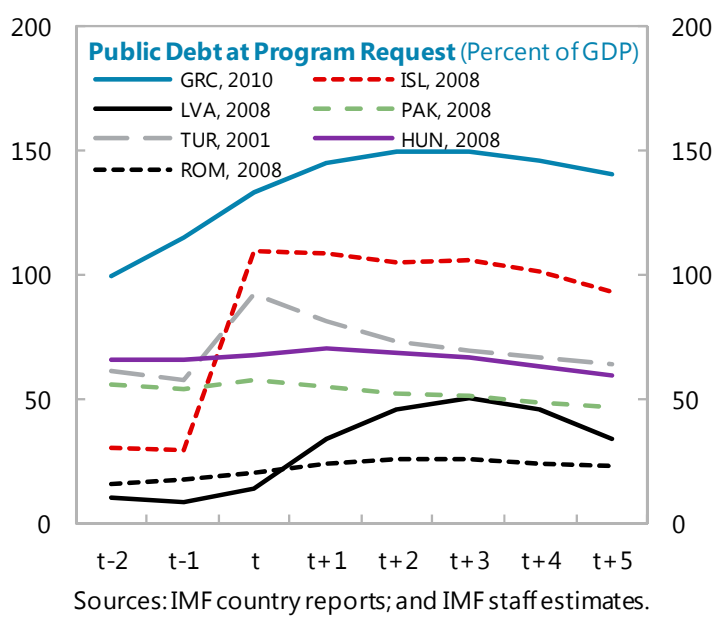
reflecting the difficult trajectory that an internal devaluation implies for debt sustainability: under a fixed exchange rate, the 
disinflation or deflation necessary to restore competitiveness serves to increase the debtGDP ratio, a trend aggravated by the contraction in real GDP. This implied a public debt profile unlike other large Fund programs with the exception of Latvia which had also fixed its exchange rate. However, public debt in Latvia was appreciably lower. In Greece, debt would peak at 149 percent of GDP only in 2013. A pending data revision was expected to raise this projection by $5-7$ percentage points.

- The program required the Fund's rules for exceptional access to be modified. To justify exceptional access, four criteria had to be met: (1) exceptional balance of payments pressures; (2) a high probability that public debt is sustainable in the medium term; (3) good prospects of regaining access to private capital markets; and (4) a reasonably strong prospect of the program's success. The sticking point for staff was Criterion 2: even with implementation of agreed policies, uncertainties were so significant that staff was unable to vouch that public debt was sustainable with high probability. But staff favored going ahead with exceptional access because of the fear that spillovers from Greece would threaten the euro area and the global economy. A proviso was therefore added to Criterion 2 that where debt was not sustainable with high probability, a high risk of international spillover effects provided an alternative justification for exceptional access. Unusually, although this is entirely legal, this change in Fund policy was made in the context of the Greece SBA Board meeting.

\section{PROGRAM STRATEGY AND IMPLEMENTATION}

15. Greece embarked on a far-reaching program of reforms in May 2010. Under the program supported by the SBA, Greece adopted an ambitious multi-year adjustment program to lower the fiscal deficit and public debt ratio, reduce domestic demand in line with supply capacity, and increase supply and competitiveness so as to invigorate investment, exports, and private sector growth. A brief history of developments under the program is provided in Box 1 which views developments under the SBA-supported program through the prism of Greece's sovereign spreads.

\section{The first pillar of the program was to drastically shrink the fiscal deficit. Fiscal} adjustment was complicated by an expected 3 percentage point of GDP rise in government interest payments over 2010-14 reflecting the replacement of low-interest debt with more expensive official (and eventually private) borrowing. ${ }^{3}$ For debt to start declining, the required adjustment in the primary balance by 2014 was $141 / 2$ percentage points of GDP. To achieve this adjustment, revenue and expenditure measures amounting to 11 percent of GDP were identified that would come on top of the 5 percent of GDP in measures implemented in the first half of

\footnotetext{
${ }^{3}$ Interest rates on the loans by euro area member states were 300 basis points over the swap rate for up to 3 years' maturity and 400 basis points above for longer maturities.
} 
2010. Reforms to tax administration and public financial management would support this effort. Major changes would also be made to the pension system to ensure its viability

17. The second pillar of the program consisted of structural reforms. Given Greece's commitment to stay in the euro and the absence of an exchange rate lever, structural reforms were necessary to facilitate internal devaluation and boost economic growth. Specific reforms were identified to increase competition in labor and product markets, boost productivity, and improve the business environment. Positive GDP growth was projected from 2012.

18. The third pillar of the program was to preserve financial stability. The banks were viewed as vulnerable to the downturn and to an adverse feedback loop from the sovereign. The Hellenic Financial Stabilization Fund (HFSF) was set up to provide capital to banks as needed. The program included $€ 10$ billion that would be available to provide resources to the HFSF if and when such needs arose.

19. The program aimed to place Greece's debt on a sustainable path. The combination of large fiscal adjustment and growth-enhancing structural reforms was projected to cut public debt to 120 percent of GDP by 2020. The program also envisaged a significant adjustment in the external current account, although this would be gradual since competitiveness would be regained slowly and external interest payments would rise. Program financing included $€ 110$ billion that was calculated as sufficient to cover the remaining fiscal deficit, the needs of the HFSF, and all government bonds falling due in 2010 and 2011. Market access was assumed to be regained in 2012.

20. The report is structured as follows. A review of program outcomes (page 12) shows that Greece's SBA-supported program had some important successes, notably regarding fiscal consolidation and pension reform. Moreover, Greece was able to stay in the euro area and international systemic spillovers were relatively well-contained. However, the SBA also failed to achieve critical objectives, especially with regard to restoring growth, ensuring debt sustainability, and regaining market access. This mixed record raises questions about the design of the program (page 20) and about whether the Fund's decision to modify its exceptional access rules to support the program was justified (page 29). The final section (page 32) reviews the possible lessons learned. 


\section{PROGRAM OUTCOMES}

Key objectives for Greece's SBA-supported program were to eliminate fiscal and current account imbalances, regain competitiveness, maintain financial stability, and boost growth and employment.

\section{A. Macroeconomic outcomes}

21. The economic downturn proved considerably more severe than projected. Data revisions complicate the comparison, ${ }^{4}$ but real GDP in 2012 was 17 percent lower than in 2009, compared to a $5 \frac{1}{2} 2$ percent decline projected in the SBA-supported program. The original growth projections were largely maintained until the fifth review (December 2011), but were then marked down with the expected recovery delayed until 2014. Projections for unemployment were raised in line with the severity of the contraction. The unemployment rate in 2012 was 25 percent compared to the original program projection of 15 percent. This huge rise in unemployment exceeded that which would be expected based on estimates of the Okun coefficient for Greece (see April 2010, WEO).

22. Other variables showed less divergence from projection. Inflation initially overshot the program projection due to the indirect tax increases, but subsequently came down as activity weakened. Prices fell by less than the decline in wages in part reflecting continued rigidities in product markets. Reductions in ULCs were wage driven with few indications that productivity had increased (see Box 2). The ULC REER is estimated to have declined by 9 percent during the period of the SBA. The current account deficit decreased broadly as projected, although by less than expected in cyclically-adjusted terms. There was a sharp compression of imports, but little pickup in exports.

\footnotetext{
${ }^{4}$ Following large data revisions due to misreporting, with Greece being found in breach of its reporting obligations under Article VIII, Section 5, the authorities took actions to improve the published data (Box 2, IMF Country Report No. 10/110). These methodological changes along with data revisions implied a shifting data landscape for the program. Eurostat did not validate the fiscal statistics until the second review (Box 1, IMF Country Report No. 10/372) and revisions to national accounts have been ongoing (a major revision in October 2012 implied that GDP in 2010 had contracted 1.4 percent more than previously reported).
} 

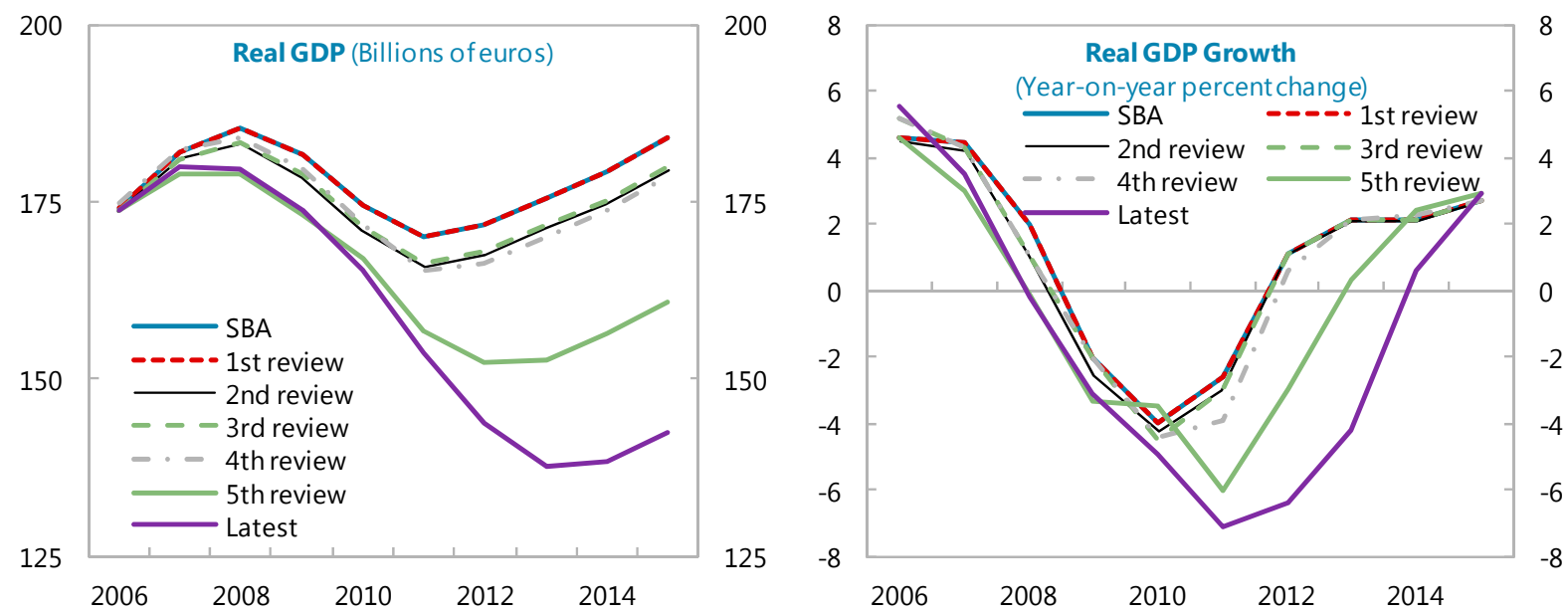

Sources: IMF country reports; and IMF staff calculations.
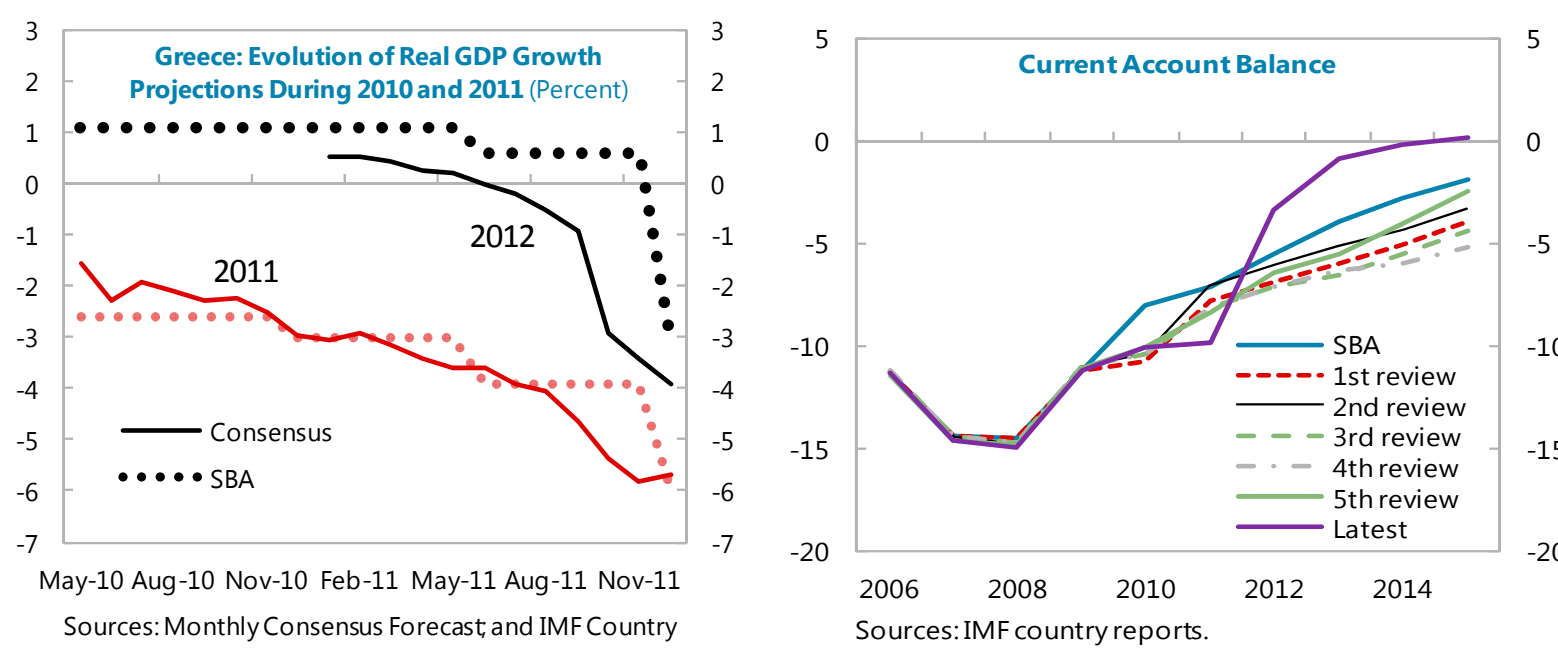

Sources: Monthly Consensus Forecast, and IMF Country Reports.
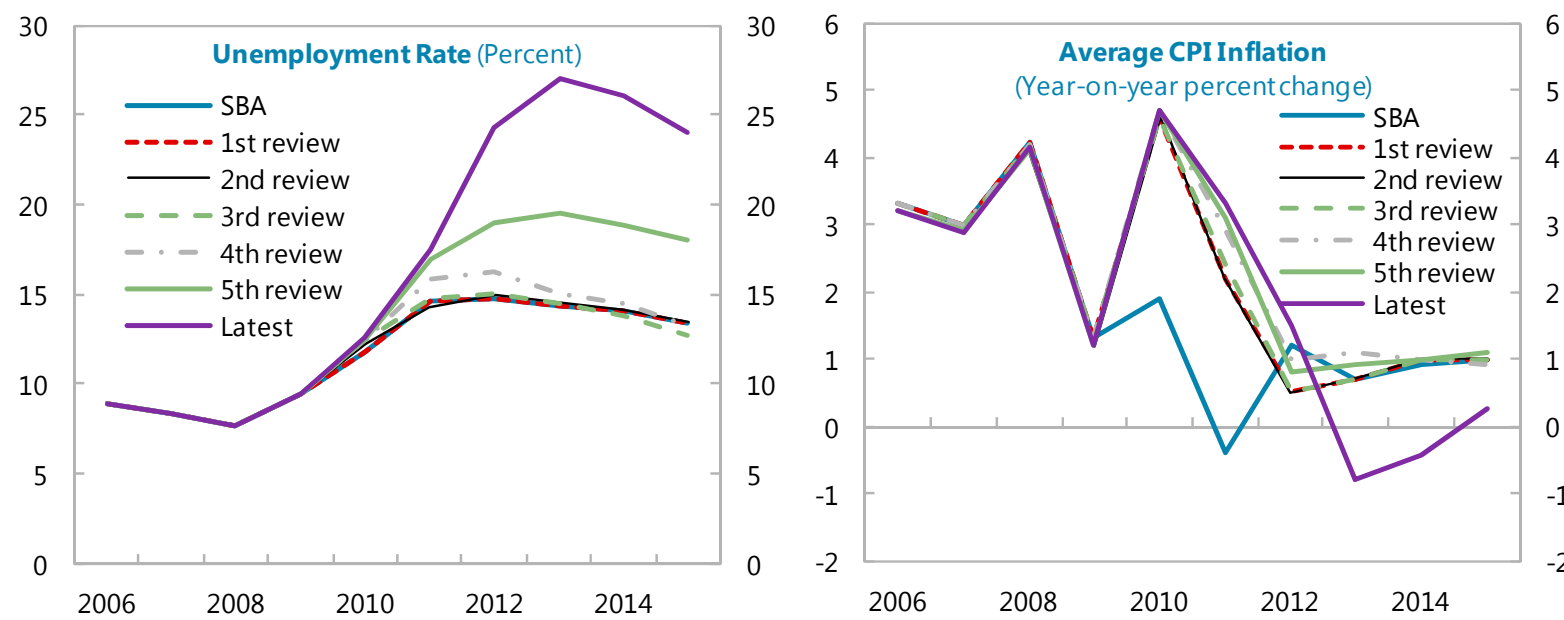

Sources:IMF country reports; IMF World Economic Outlook; and IMF staff calculations. 


\section{B. Fiscal policy outcomes}

23. A large reduction in the fiscal deficit was achieved. The change in the primary deficit during 2010-11 was 8 percentage points of GDP, slightly above target, despite the deep recession. The authorities introduced additional measures in 2011 (Medium-Term Fiscal Strategy, amounting to 101/2 percent of GDP during 2011-14) once it became clear that the initial set of fiscal measures was insufficient to deliver the consolidation target. In cyclically-adjusted terms, the primary balance improved by about 13 percent of potential GDP during the SBA. ${ }^{5}$ Estimates of the debt-stabilizing level of the primary surplus were reduced from the fifth review once private sector involvement (PSI) reduced the debt stock and lowered the average interest rate on public debt. ${ }^{6}$

24. Taxes were increased further. Revenue measures had already been taken in May 2010 under the 2010 Stability program including increases in VAT rates. Additional tax policy measures implemented during the SBA-supported program comprised increases in indirect tax rates, including further VAT rate hikes, a new property tax, and somewhat higher income taxes. Efforts were also made to strengthen tax administration and raise tax collections.

\section{Expenditure measures focused on reducing public sector wages and social benefits.}

Public sector wages and pensions were cut through elimination of $13^{\text {th }}$ and $14^{\text {th }}$ monthly payments, but with safeguards intended to protect the most vulnerable. Measures implemented in 2010-11 included cuts in public sector salaries, bonuses, and allowances, and steps to reduce health care spending on drugs. Other measures included cuts in capital spending and a reorganization of subnational governments (Kalikrates). The authorities also adopted a new budget framework and put in place spending control mechanisms. Nonetheless, arrears and inadequate data reporting remained an issue throughout the SBA-supported program.

\footnotetext{
${ }^{5}$ The performance criterion on the general government primary cash balance was met for end-2010 but this is exaggerated to some extent by a build-up in domestic arrears: during 2010, this performance criterion did not take account of the accumulation of arrears (monitored via an indicative target that was breached by $€ 3$ billion, or a bit over 1 percent of GDP). The definition of the performance criterion was subsequently modified to incorporate domestic arrears.

${ }^{6}$ Debt restructuring in March 2012 led to a 60 percent reduction in privately held debt. Public debt fell by $€ 62.4$ billion to $€ 305.5$ billion. Some relief was also provided on official debt in March and December 2012 including a reduction in interest rates on the euro area loans. See Zettelmeyer et al (2013).
} 

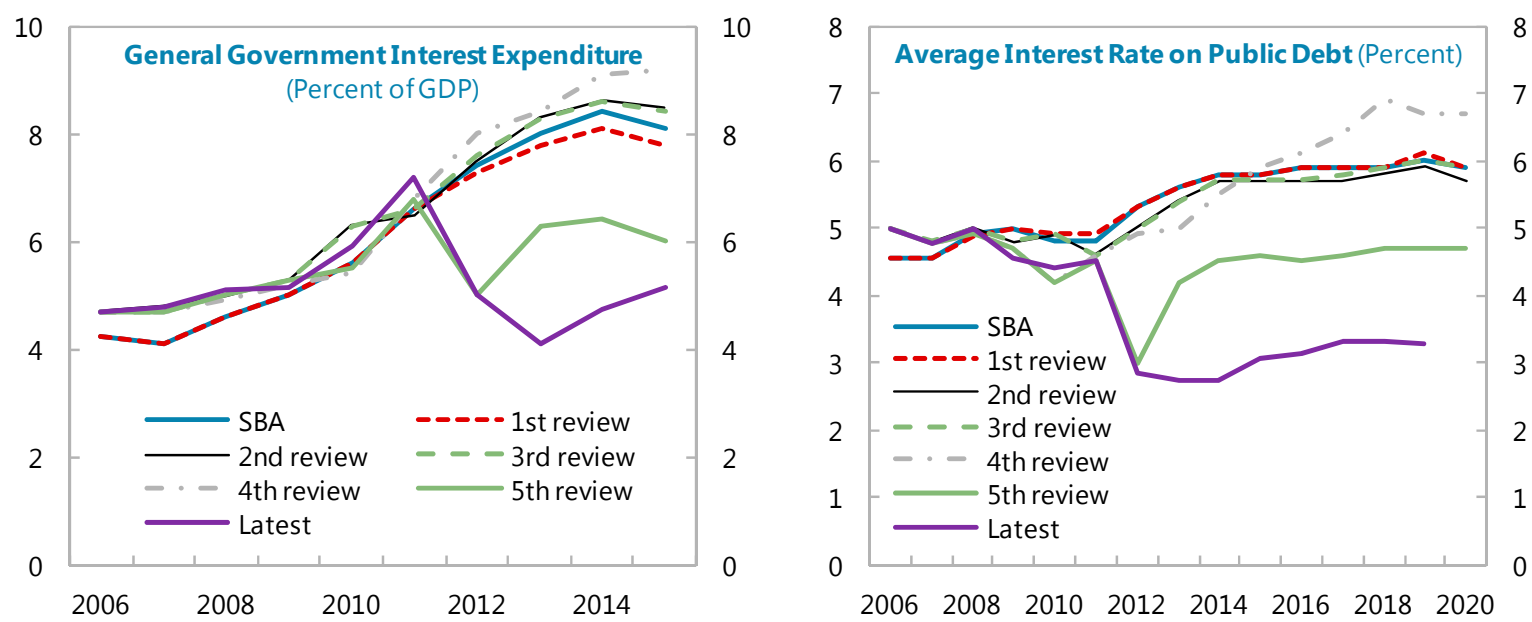

Sources: IMF country reports.
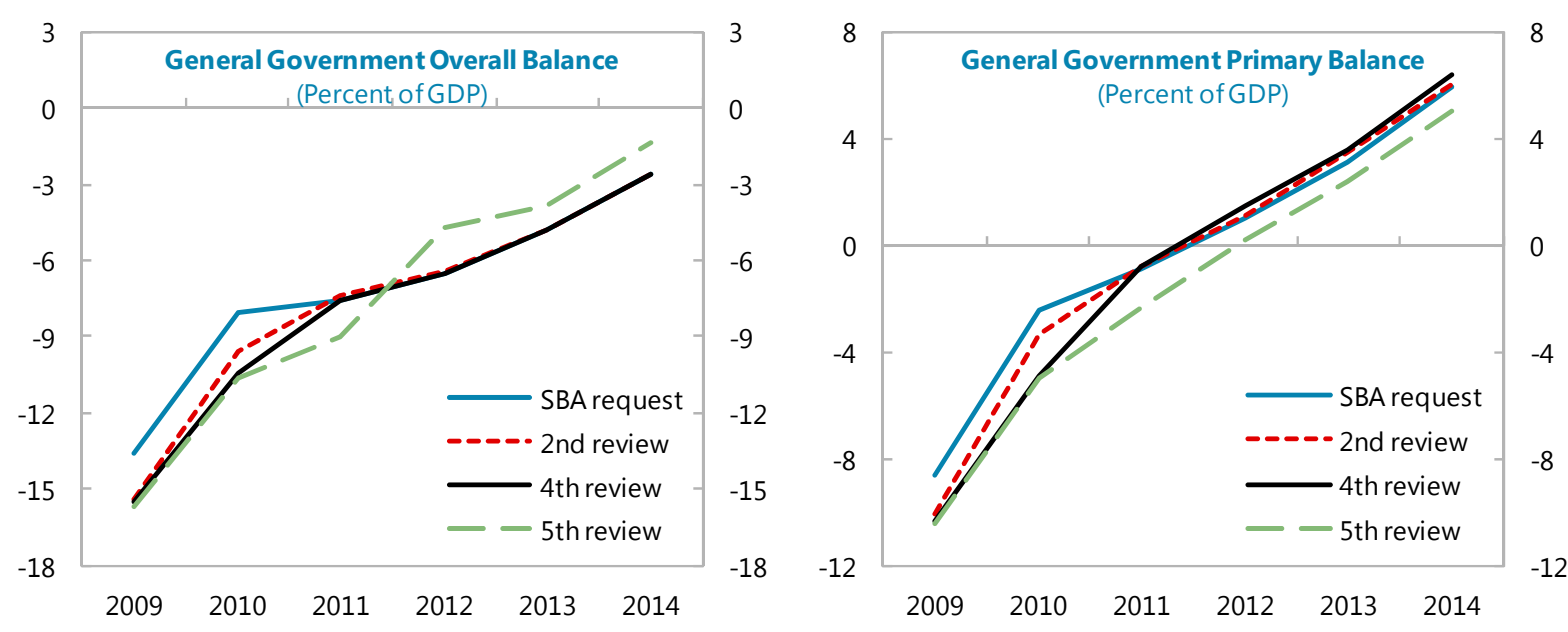

Sources:IMF Country Reports; and IMF staff estimates.

General Government Operations, 2009-11

(Percent of GDP)

\begin{tabular}{|c|c|c|c|c|c|c|c|c|}
\hline & \multicolumn{2}{|c|}{2009} & \multicolumn{2}{|c|}{2010} & \multicolumn{2}{|c|}{2011} & \multicolumn{2}{|c|}{ Change, 2009-11 } \\
\hline & SBA Request & Est. & SBA Request & Est. & SBA Request & Est. & SBA Request & Est. \\
\hline Revenue & 36.9 & 38.3 & 40.5 & 40.6 & 42.5 & 42.4 & 5.6 & 4.1 \\
\hline Expenditure & 50.4 & 54.0 & 48.5 & 51.4 & 50.1 & 52.0 & -0.3 & -2.0 \\
\hline Primary & 45.4 & 48.8 & 42.9 & 45.5 & 43.5 & 44.8 & -1.9 & -4.0 \\
\hline Interest & 5.0 & 5.2 & 5.6 & 5.9 & 6.6 & 7.2 & 1.6 & 2.0 \\
\hline Overall balance & -13.6 & -15.6 & -8.1 & -10.8 & -7.6 & -9.6 & 6.0 & 6.0 \\
\hline Primary balance & -8.6 & -10.5 & -2.4 & -4.9 & -0.9 & -2.4 & 7.7 & 8.1 \\
\hline $\begin{array}{l}\text { Cyclically-adjusted } \\
\text { primary balance } 1 /\end{array}$ & -16.0 & -14.0 & -7.8 & -6.3 & -5.8 & -1.3 & 10.3 & 12.7 \\
\hline
\end{tabular}

Sources: Eurostat; and IMF staff calculations.

1/ Percent of potential nominal GDP. 
26. About half of the adjustment in the primary deficit reflected lower spending. As a result of the expenditure measures undertaken during the SBA-supported program, primary expenditure declined by 4 percentage points of GDP in 2009-11, but still exceeded the 2005 level by about the same amount. Moreover, the wage bill remained high compared with other EU countries; programs for social protection remained largely untargeted and inefficient (OECD, forthcoming); and health care reform had yet to be completed.

\section{Fiscal consolidation proceeded, but} momentum on fiscal structural reforms flagged. Measures taken contributed to strong upfront consolidation (wage and pension cuts, VAT hikes)

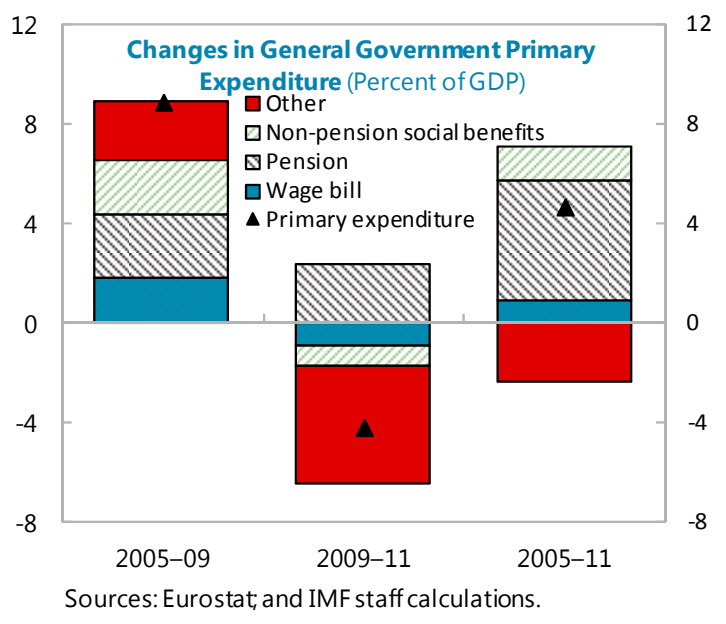
and to improved long-term sustainability (pension reform). A far-reaching pension reform was approved by Parliament in July 2010 that was designed to substantially contain increases in pension benefits over the long run (see Box 3). Fund TA also led to improvements in expenditure and commitment controls and to better fiscal reporting and budgeting practices. However, tax administration reforms encountered setbacks due to political resistance and capacity constraints. Although TA led to improvements in on-time VAT filing, there were few signs by the end of the SBA-supported program that collection efficiency was being improved on a permanent basis (see Box 4).

\section{Debt and financing outcomes}

28. Public debt overshot program projections by a large margin. The debt sustainability analysis (DSA) in the program request included stress tests but these turned out to be mild compared to actual outcomes. At the outset of the program, debt was projected to peak at 154156 percent of GDP in 2013 (depending on data revisions). However, by the fourth review in July 2011 (i.e., before PSI was in prospect), the end-2013 debt ratio was projected at 170 percent of GDP. As the program unfolded, the underlying debt dynamics worsened significantly because output contractions and deflation were more pronounced than expected. Lower nominal growth raised the interest rate-growth differential and led to progressively higher expected debt paths. Data revisions affecting both public debt and GDP exacerbated these trends. 

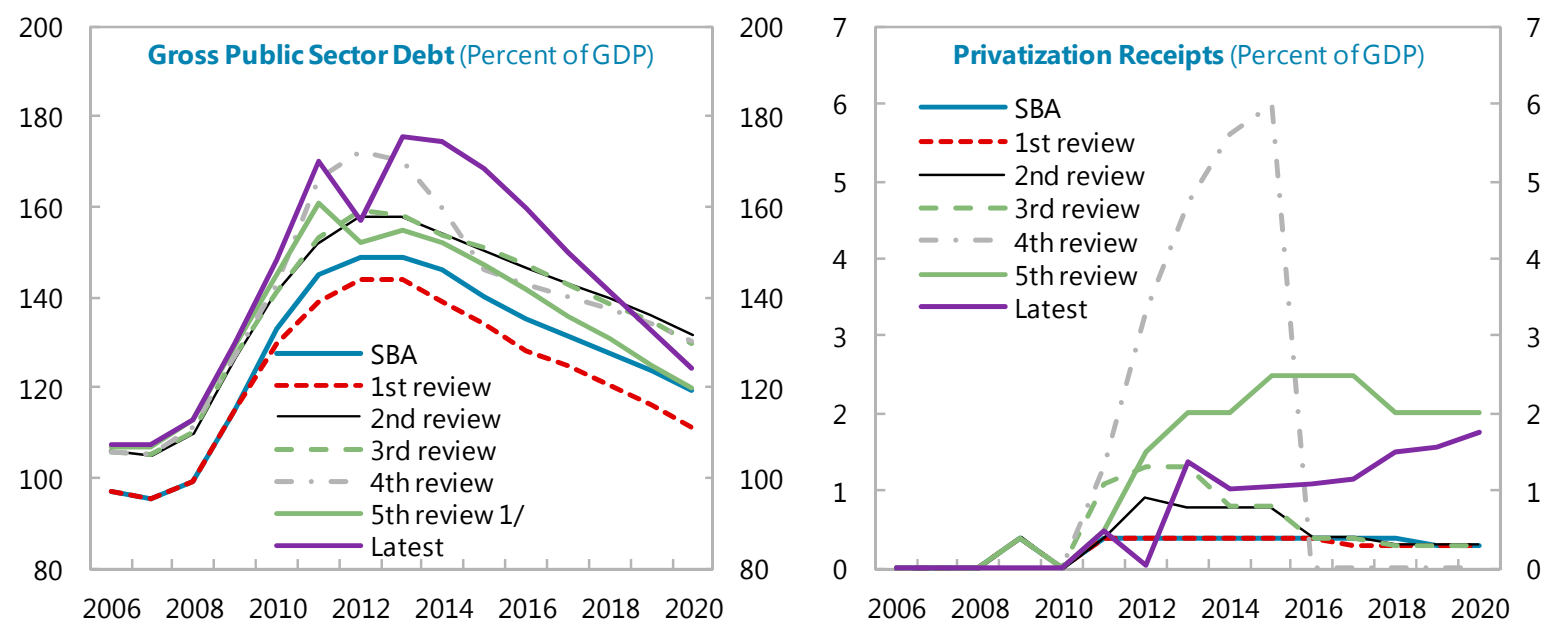

Sources:IMF country reports.

1/ Already incorporated effects of debt restructuring.

29. Privatization outcomes were disappointing. The authorities signaled a strong commitment to privatization in mid-2011 with parliamentary approval of a privatization and real estate development strategy. However, despite little progress having been made to date, the fourth review made extremely optimistic assumptions about privatization with envisaged receipts rising to $€ 50$ billion compared to about $€ 10$ billion in the original program. Such receipts became less important for debt sustainability from the fifth review once PSI was in prospect, plus equity prices had by that stage come down sharply. In the fifth review, much lower projections for privatization receipts were made and in general the DSA was cast with more conservative assumptions.

30. Weaker macroeconomic outturns and eventual PSI exerted opposite effects on debt sustainability. Adjusting the debt projections under the original SBA with the macro figures used in the January 2013 review of the EFF-supported program (and for subsequent data revisions to debt and GDP) show public debt at about 180 percent of GDP in 2020. The debt restructuring, however, provided more than an offset and the latest projections show debt declining to about 120 percent of GDP by 2020 .

\section{Private creditors were} able to significantly reduce their exposure. Non-resident holdings of government debt dropped sharply in 2010-12. Resident holdings of government debt initially rose, but then started to fall

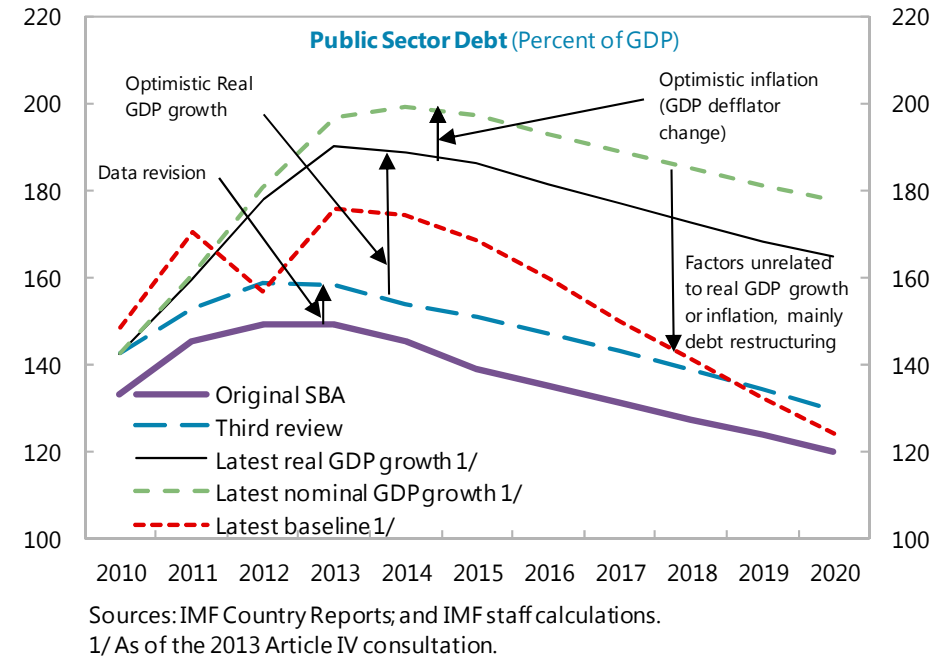


as well. There was a large-scale substitution from privately-held to publicly-held debt. Part of this was by design-program financing was to be used to repay maturing bonds in 2010 and 2011 — but the shift was intensified by market access not being regained in 2012, as well as by SMP. Purchases of Greek government bonds under SMP created rigidities when debt was restructured as a result of the decision to exclude SMP (and euro area national central bank) bond holdings from the PSI.

\section{Structural reforms}

\section{Labor market reforms encountered} resistance under the SBA-supported program.

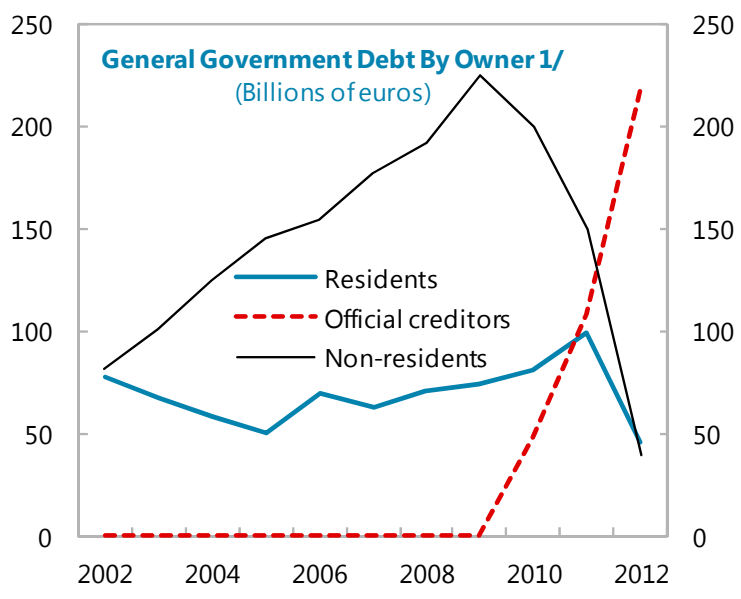

Sources: Greek authorities; and IMF staff estimates. 1 / Assumes that the stock of bonds in the ECB's SMP as of end-2012 was purchased evenly over 2010-1. Bonds held by Eurosystem central banks, EC, and EIB for investment purposes are not treated as debt to official creditors.

Labor market reforms were initially judged to be progressing well, but a more critical view was taken in later reviews. The wage bargaining system was reformed, but there were few firm level agreements and the Fund judged labor market reforms not to have delivered enough flexibility. The absence of early actions to reduce private wages may have aggravated the job losses from the economic downturn. ${ }^{7}$

\section{The product market and regulatory environment also proved resilient to change.}

Although the initial momentum appeared strong, reforms to product markets and the business environment failed to generate a critical mass necessary to boost growth. Program reviews reported that progress was disappointing. For example, one-stop-shops and fast-track investment approval laws were passed, but implementation was delayed. While the law liberalizing regulated professions was also passed, the deadline for requesting reinstatement of justified restrictions was postponed thus delaying implementation. This slow progress militated against realization of the productivity gains that had been hoped for in the program.

\section{E. Financial sector}

\section{The banking system was perceived to be relatively sound when the program began.}

The bank capital ratio was 11.7 percent aided by a recapitalization in 2009, but balance sheets came under pressure from higher nonperforming loans (NPLs) once the economy weakened. Moreover, liquidity conditions tightened in 2009 due to banks losing wholesale market access and some deposit outflows.

\footnotetext{
${ }^{7}$ It was only with the approval of the EFF in March 2012 that significant labor reforms took place including cuts in minimum wages in the private sector.
} 


\section{As the recession intensified and liquidity tightened, the financial sector became} increasingly vulnerable. Financial sector distress was a result of the protracted recession and sovereign debt problems. This was in contrast to Ireland and Spain where causality ran the other way. By 2011, deleveraging in the financial sector and restructuring of state-owned banks was perceived necessary. ATE, the largest state-owned bank and the only Greek bank to fail the Europe-wide stress tests in mid-2010, had to be recapitalized. Sizable deposit outflows began in the second half of 2011, fanned by fears of a Greek euro exit.
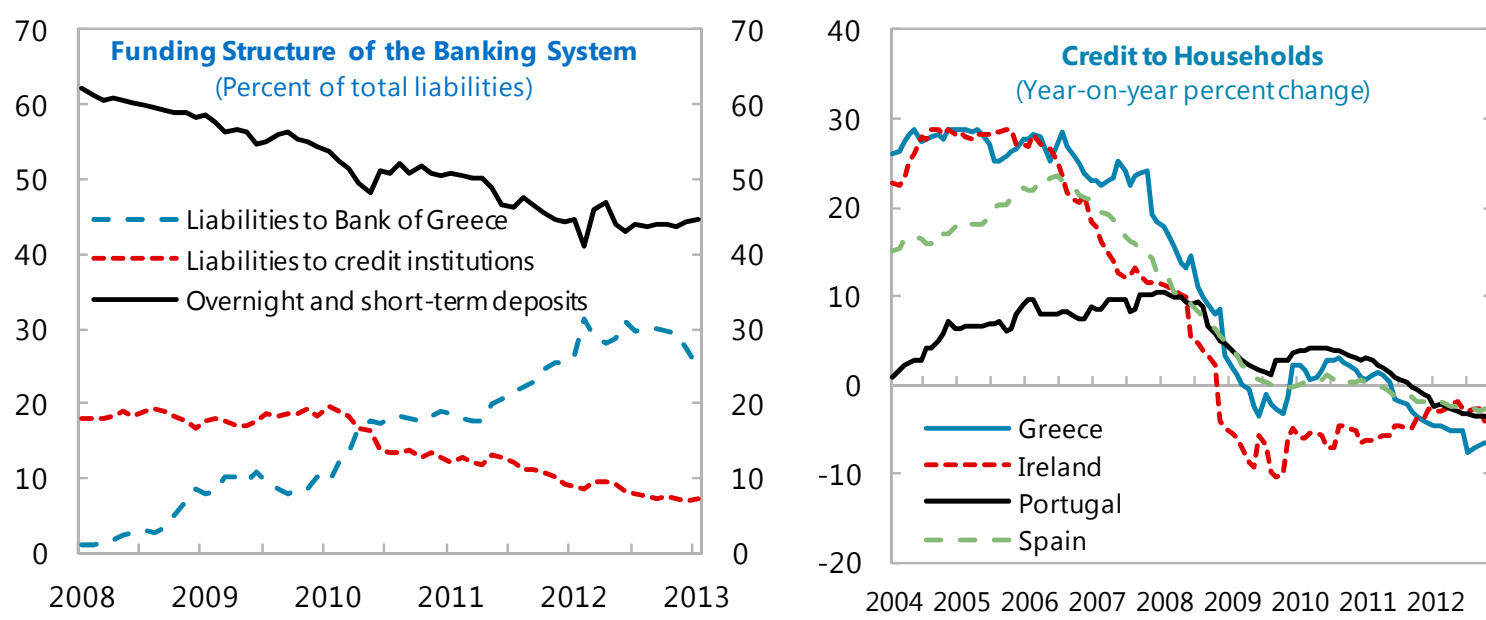

Sources: Bank of Greece; Eurostat; Haver, and Fund staff calculations.
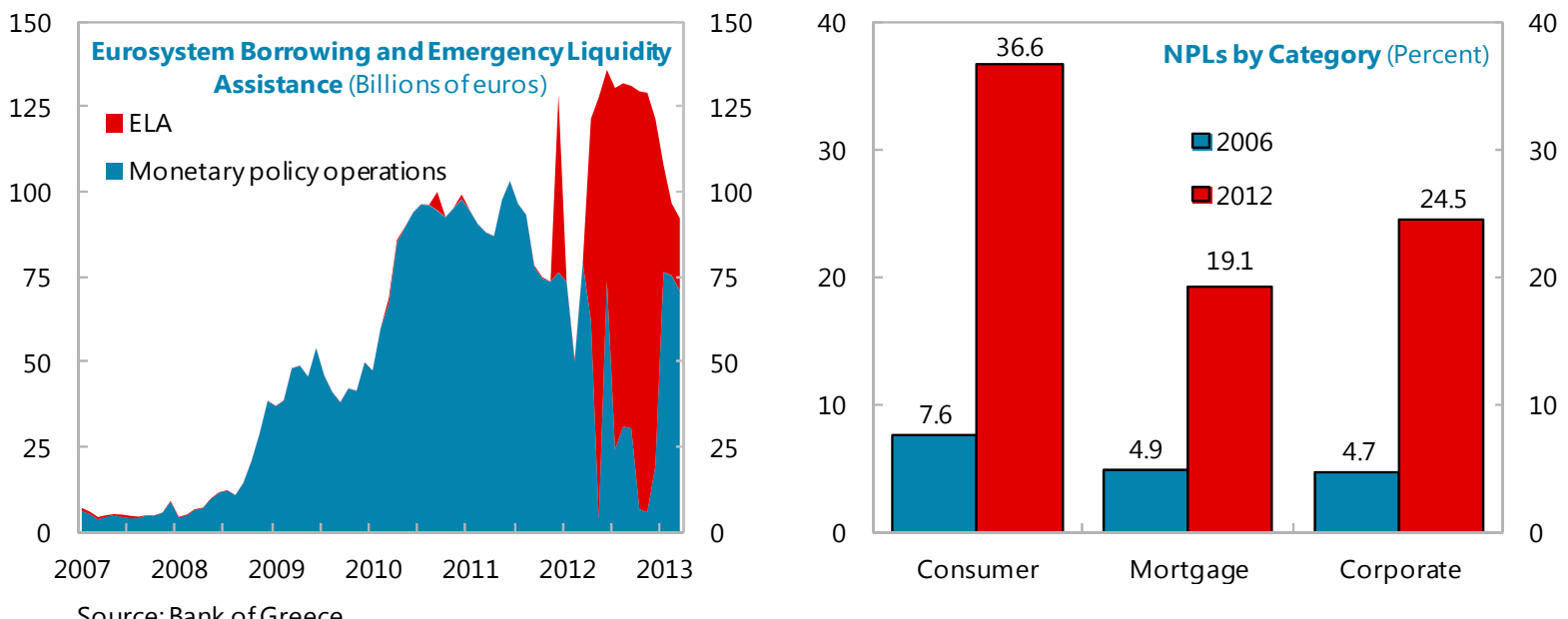

36. The ECB provided substantial and extraordinary liquidity support. As noted, from May 2010, the ECB suspended the link between sovereign credit ratings and eligibility of collateral for refinancing operations and intervened directly in the government bond market under the SMP. The ECB also began to accept uncovered bank bonds guaranteed by the government as collateral eligible for refinancing operations.

37. PSI served to eliminate the banks' capital. Greek banks were heavily exposed to the sovereign, holding government bonds with a book value of about $€ 40$ billion (after some initial 
June 2011 impairments). By contrast, core capital was $€ 22$ billion, or about the same magnitude as the capital needs arising from the PSI. Only $€ 1.5$ billion was drawn from the HFSF during the SBA-supported program, but the banks' capital needs subsequently dwarfed the HFSF provision. As of the fourth review the purpose of the HFSF changed from a means of topping up capital for banks that had tried and failed to raise private capital to providing a substantial injection of public funds for banks that had been severely affected by the PSI and the deep recession: the amount needed for the HFSF in the context of the EFF was estimated at $€ 50$ billion.

\section{PROGRAM DESIGN}

While significant fiscal adjustment occurred during the SBA, critical objectives such as regaining confidence and restoring growth were not achieved. This raises important questions about the design of the program.

\section{A. Should the fiscal adjustment path have been more gradual?}

\section{It is difficult to argue that adjustment should have been attempted more slowly.}

The required adjustment in the primary balance, $14 \frac{1}{2}$ percentage points of GDP, was an enormous adjustment with relatively few precedents, ${ }^{8}$ but was the minimum needed to bring debt down to 120 percent by 2020. Moreover, despite the starting point being slightly worse than thought to be the case when the 2010 Stability Program was drawn up, ${ }^{9}$ the SBA-supported program had already extended the period over which the Maastricht deficit target would be achieved from 3 to 5 years. Since the program only ran through mid-2013, the last part of this adjustment would occur after the program and the conditionality had ended. ${ }^{10}$ Moreover, debt would still be increasing when the program ended.

\begin{tabular}{|lrrrrrrr|}
\hline \multicolumn{7}{|c|}{ Targeted Fiscal Adjustment: Overall Deficit } \\
(Percent of GDP) \\
\hline 2009 & 2010 & 2011 & 2012 & 2013 & 2014 \\
\hline SP, Jan., 2010 ("4-3-3") & 12.5 & 8.8 & 6.0 & $\leq 3.0$ & $\leq 3.0$ & $\leq 3.0$ \\
SBA, May, 2010 & 13.6 & 8.1 & 7.6 & 6.5 & 4.8 & 2.6 \\
\hline Sources: Greece's 2010 Stability Program; and IMF Country Report No. 10/110. \\
\hline
\end{tabular}

\footnotetext{
${ }^{8}$ Episodes of comparable large fiscal adjustments include Greece where in at least two instances (in 1978 and 1990) the annual contraction in the primary deficit amounted to over 7 percent of GDP (see Tsibouris et al, 2006). However, the required adjustment under the SBA-supported program would be undertaken in a very weak global growth environment.

9 In April 2010, the estimated fiscal deficit for 2009 was revised to $131 / 2$ percent of GDP from the $12 \frac{1}{2}$ percent of GDP estimate that prevailed when the 2010 Stability Program was formulated.

${ }^{10}$ This raises the issue of why an EFF was not introduced from the outset - see discussion below.
} 


\section{More importantly, a flatter adjustment path would have required more than}

$€ \mathbf{1 1 0}$ billion in financing. The Greek SBA was already the highest access loan in Fund history. While the euro partners could have provided more than $€ 80$ billion in funding (although this was already more than 35 percent of Greek GDP), this would have been politically difficult. Debt restructuring could also have provided the authorities with some leeway, but as discussed below, this option was not politically feasible.

\section{B. Should the adjustment path have been more flexible?}

40. The scope for increasing flexibility was also limited. The fiscal targets became even more ambitious once the downturn exceeded expectations. In addition, the starting point moved. ${ }^{11}$ However, the automatic stabilizers were not allowed to operate and adjustments were not made to the fiscal targets until the fifth review in December 2011. While earlier adjustment of the targets could have tempered the contraction, the program would then have required additional financing. The date by which debt started to decline would also have been stretched beyond the program period.

\section{Should the larger economic downturn have been expected?}

\section{There were a number of reasons why the actual decline in GDP was so much greater than anticipated:}

- The fiscal multipliers were too low.. The question that arises is whether underestimation of the size of the fiscal multipliers in the SBA-supported program caused the depth of the recession to be underestimated. The program initially assumed a multiplier of only 0.5 despite staff's recognition that Greece's relatively closed economy and lack of an exchange rate tool would concentrate the fiscal shock. Recent iterations of the Greek program have assumed a multiplier of twice the size. This reflects research showing that multipliers tend to be higher when households are liquidity constrained and monetary policy cannot provide an offset (see October 2012 WEO), influences that appear not to have been fully appreciated when the SBA-supported program was designed. Aslund (2013) has also argued that there is a habitual tendency of Fund programs to be over-optimistic on growth until the economy reaches a bottom (and thereafter to underestimate the recovery). ${ }^{12}$

- However, the deeper-than-expected contraction was not purely due to the fiscal shock. Part of the contraction in activity was not directly related to the fiscal adjustment, but rather reflected the absence of a pick-up in private sector growth due to the boost to productivity

\footnotetext{
${ }^{11}$ The estimated 2009 fiscal deficit was revised again in December 2010 from 131/2 to 151/2 percent of GDP.

12 By contrast, the Fund's 2011 Conditionality Review finds that growth projections for program countries do not display a bias in the aggregate (contrary to past studies, which found an optimistic bias). See IMF (2012a).
} 
and improvements in the investment climate that the program hoped would result from structural reforms. Confidence was also badly affected by domestic social and political turmoil and talk of a Greek exit from the euro by European policy-makers. ${ }^{13}$ On the other hand, the offset to the fiscal contraction from higher private sector growth that was assumed during the program period appears to have been optimistic (see Section D below), while some of the adverse political developments were endogenous and followed from limited ownership of the program (see Section $\mathrm{F}$ below). A larger contraction should probably therefore have been expected, although it should be noted that market forecasters were no more accurate. ${ }^{14}$

42. In any event, a deep recession was unavoidable. Greece lost market access in the first half of 2010 with a fiscal deficit so large and amortization obligations so onerous that it is difficult to see how a severe economic contraction could have been avoided. Indeed, if Greece had defaulted, the absence of deficit financing would have required primary fiscal balance from the second half of 2010. This would have required an abrupt fiscal consolidation, and led to an evaporation of confidence and huge deposit outflow that would have most likely made the contraction in output even larger.

\section{Were structural reforms sufficient to restore competitiveness and growth?}

43. Structural reforms were critical to improving competitiveness. The program had to work within the constraints of the fixed exchange rate and engineer an internal devaluation. Part of the adjustment in ULCs would come from the economic slowdown that would exert downward pressure on wages. The rest would follow from structural reforms that would free up Greece's rigid labor and product markets and raise productivity.

44. Actions were not taken to adjust private sector wages. While the program cut wages and bonuses in the public sector, there were no direct attempts to lower private sector wages. The EC took the view that forcing reductions in private wages, for example, through abolition of bonuses, was not critical: industry did not consider labor cost to be excessive and in any case exports were unlikely to be wage sensitive. ${ }^{15}$ Instead focus was on increasing the scope for wage

\footnotetext{
${ }^{13}$ External demand also weakened during the program period: the April 2010 WEO projected cumulative GDP growth in the Eurozone in 2010-12 of 3.2 percent compared to an outturn of 1.0 percent. However, this would have played a limited role in worsening the contraction given the small size of Greece's export sector.

14 The program growth projections (-4 percent in 2010 and -2.6 percent in 2011) were more pessimistic than the May 2010 Consensus Forecasts (-3.6 percent in 2010 and -1.6 percent in 2011).

${ }^{15}$ See European Commission (2010). Also see Papaconstantinou (2010): "Competitiveness is a broader issue than wages in Greece and also has to do with the oligopolistic nature of markets: wage cost is part of the discussion but not a main element."
} 
bargaining at the firm level. The Fund agreed with the emphasis on bringing down public sector wages, noting the strong demonstration effect that this would have for the private sector.

45. A quick recovery in growth appeared optimistic. Internal devaluation was recognized to be a gradual process. In fact, the program projections implied that only about 3 percent of the estimated 20-30 percent improvement required in competitiveness would be achieved by 2013 .

This assumption aided the debt sustainability analysis by limiting the decline in the denominator in the debt-GDP ratio, but also raised a fundamental question about where growth would come from in the absence of an internal devaluation. The program emphasized confidence effects, regained market access, and completed structural reforms. However, even if structural reforms were transformative, a quick supply response was unlikely. Partner country growth was also expected to be weak. Nonetheless, the program assumed a V-shaped recovery from 2012.

\section{E. Was the mix of fiscal measures appropriate?}

\section{The adjustment mix seems revenue heavy given that the fiscal crisis was expenditure driven. As discussed earlier, the} ballooning of the fiscal deficit in the 2000s was almost entirely due to increased expenditure. The large dose of revenue measures in the SBA-supported program can therefore be questioned, particularly since tax changes constituted almost half of the measures targeted for the first two years of the program. ${ }^{16}$ The case for indirect tax increases was that they were quick to take effect and faced less resistance than cuts in spending programs. Moreover, VAT rates were lower than the median level in Europe.

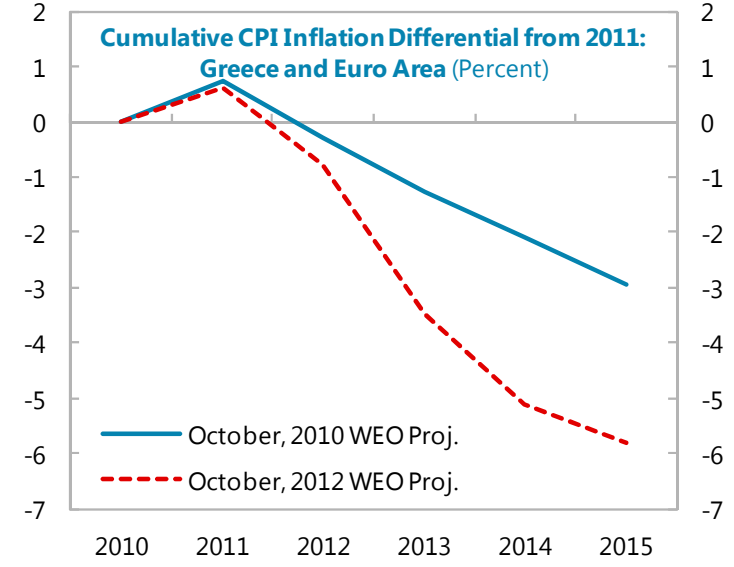

Sources: IMF, World Economic Outlook, and IMF staff calculations.

\begin{tabular}{|c|c|c|c|c|c|}
\hline \multicolumn{6}{|c|}{$\begin{array}{l}\text { Composition of Measures } \\
\text { (Percent of GDP) }\end{array}$} \\
\hline & 2010 & 2011 & 2012 & 2013 & Cum. \\
\hline Total & 2.5 & 4.1 & 2.4 & 2.0 & 11.1 \\
\hline Revenue & 0.5 & 3.0 & 0.8 & -0.3 & 4.0 \\
\hline Excises & 0.2 & 0.3 & 0.1 & $\ldots$ & 0.6 \\
\hline VAT & 0.3 & 0.9 & 0.2 & $\ldots$ & 1.5 \\
\hline РIT & $\ldots$ & 0.2 & 0.0 & $\ldots$ & 0.2 \\
\hline $\mathrm{C} \Pi$ & $\ldots$ & 0.4 & $\ldots$ & $\ldots$ & 0.4 \\
\hline Property tax & $\ldots$ & 0.8 & 0.1 & 0.0 & 0.9 \\
\hline Other & $\ldots$ & 0.4 & 0.3 & -0.3 & 0.4 \\
\hline Expenditure & 2.0 & 1.1 & 1.7 & 0.5 & 5.3 \\
\hline Wages & 0.5 & 0.2 & 0.3 & 0.2 & 1.2 \\
\hline Pensions & 0.8 & 0.3 & 0.1 & 0.1 & 1.3 \\
\hline Social benefits & 0.2 & 0.0 & 0.2 & $\ldots$ & 0.4 \\
\hline Goods and services & 0.3 & 0.4 & 0.2 & 0.2 & 1.1 \\
\hline Subsidies & $\ldots$ & $\ldots$ & 0.7 & $\ldots$ & 0.7 \\
\hline Investment & 0.2 & 0.2 & 0.2 & $\ldots$ & 0.7 \\
\hline Structural reforms & $\ldots$ & $\ldots$ & $\ldots$ & 1.8 & 1.8 \\
\hline
\end{tabular}

${ }^{16}$ There is also evidence that expenditure-based fiscal adjustment is more durable (see Tsibouris et al, 2006). 
47. The burden of adjustment was not shared evenly across society. The public sector wage bill was cut by lowering wages and bonuses, but specific plans to downsize the number of civil servants were limited to a commitment to replace only 20 percent of those who retired. The state enterprises also remained generously staffed. By contrast, the private sector sustained enormous job losses partly because wage setting mechanisms were not liberalized. Moreover, little progress was made in checking tax evasion by high income earners. While the program recognized that it would take time to show results from improved tax administration, the absence of quick progress in collecting evaded taxes came at the cost of any demonstrable improvement in the equity of the tax burden.

Government Effectiveness, 2011 1/

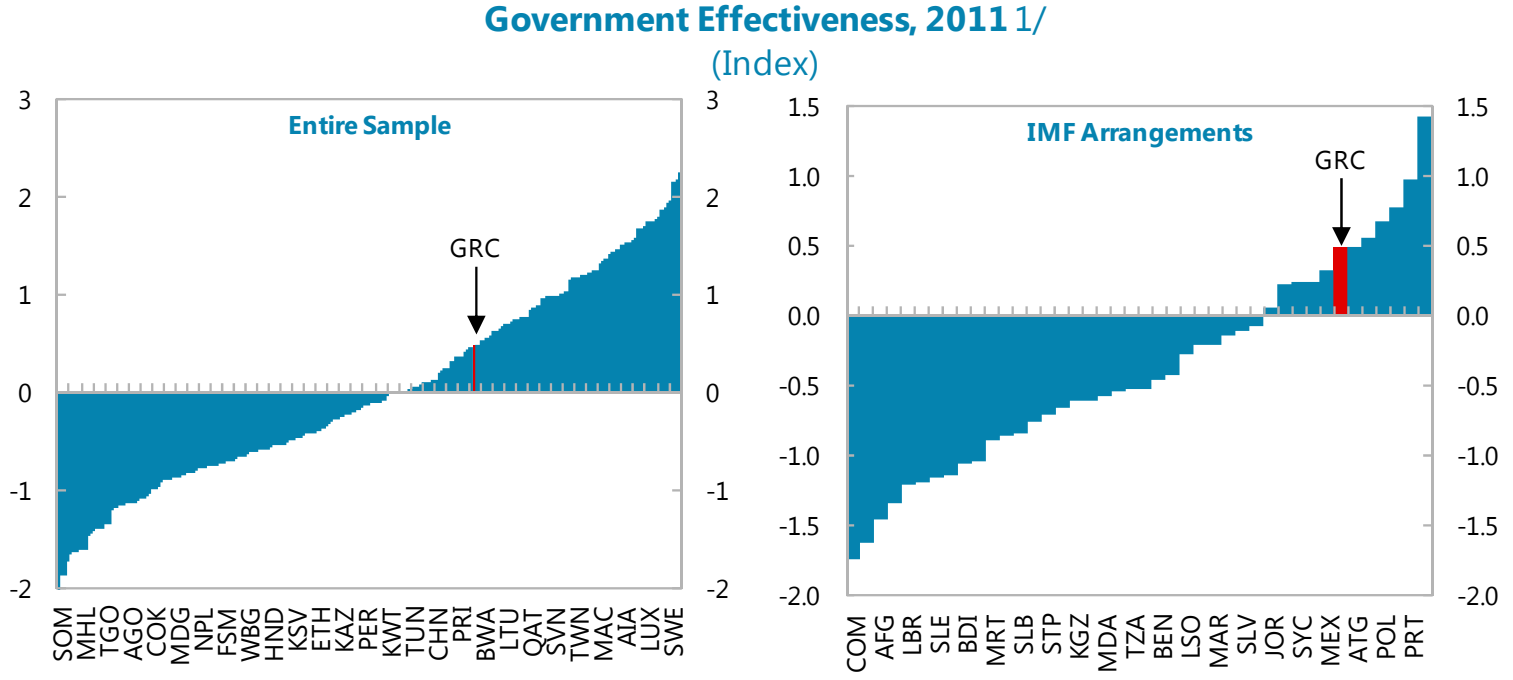

Source: World Bank, Worldwide Governance Indicators. $1 /$ Selected countries shown on the $X$ axis.

\section{F. Was there sufficient ownership and capacity for reforms?}

48. Ownership of the program was limited. Staff recognized that vested interests had fiercely opposed structural reforms in Greece in the past, but were encouraged by the authorities' strong commitment to the program. The government also had a fresh mandate from the election and a strong majority in parliament. Staff argued that difficult actions, such as cutting public sector wage levels, were being taken as prior actions, while Fund and EC technical assistance would support the program of reforms. As it turned out, ownership of the program did not extend far and little progress was made with politically difficult measures such as privatization, downsizing the public sector, and labor market reforms. There was also limited bipartisan support in parliament for the program, while relations with unions were adversarial and there was little hope that that an incomes policy could be agreed.

49. The capacity to implement reforms was overestimated. The Fund had concerns that implementation capacity might be weak based on its history of providing fiscal technical assistance to Greece. However, the extent to which administrative capacity was lacking in the public sector seems to have come as a surprise. The depth of contact afforded by annual Article 
IV surveillance may not have provided much insight. Moreover, World Bank indicators do not show government effectiveness in Greece to be particularly low by global standards, although they are relatively low for an advanced country.

50. Structural conditionality became very detailed. In recent years, the Fund has moved toward concentration on macro-critical structural reforms in programs and more parsimony in setting conditionality. The number of structural conditions set under the SBA-supported program was relatively large (see Box 5), although there seems to be less of a case for parsimony when formulating competitiveness-boosting reforms in a case like Greece where the exchange rate is fixed. However, the number of fiscal structural conditions was also large, and became more so as the program progressed. By the fifth review, one of the fiscal structural prior actions had nine sub-prior actions. This proliferation of conditions reflected the realization of the extent of the weaknesses in administrative capacity. While, according to available government effectiveness indicators, Greece is far from an outlier in terms of weak capacity among countries with Fundsupported programs, administrative capacities in Greece do appear to be extremely weak. Moreover, fiscal technical assistance is delivered in cooperation with the EC, whose capacity building initiatives tend to be very detailed.

\section{G. Was the financing of the program likely to be sufficient?}

51. The adequacy of the program financing required favorable assumptions. Markets were concerned about the problem of large repayment obligations in 2014 and 2015 after the program expired. The financing strategy assumed renewed market access from 2012 yet the composition of debt holders would now deter private lenders since official lenders tend to be senior creditors. Subsequent research also suggests that the market access assumption, assessed in terms of rollover rates, was sanguine compared to past experience in emerging markets facing exogenous shocks (see IMF, 2011). However, Greece's advanced economy status and its membership of the euro area may have been considered as modifying factors.
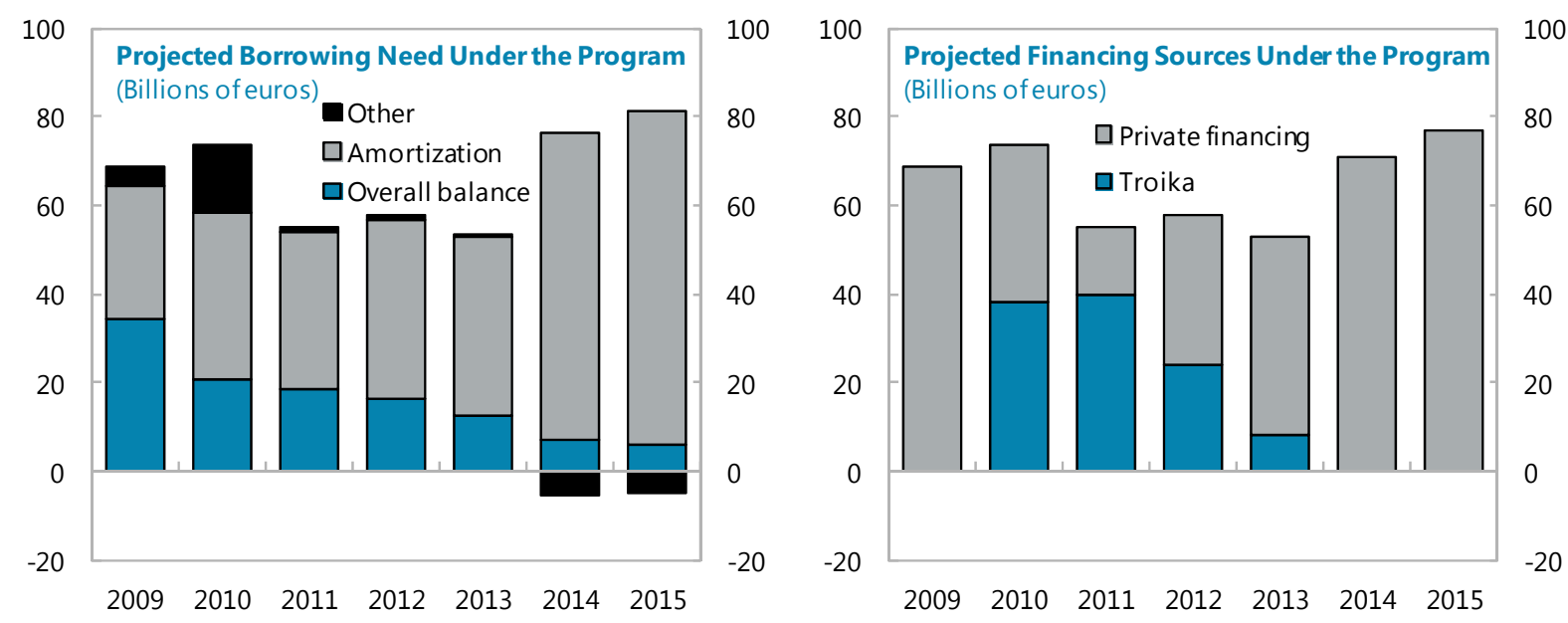

Sources: IMF Country Report No. 10/110; and IMF staff estimates. 
52. The financing available for the capital needs of the banking sector was also all

likely to be needed. The HFSF was established to safeguard the stability of the banking sector with up to $€ 10$ billion from program disbursements. The 2009 Article IV Consultation had reported results of banking system stress tests that showed that if a number of shocks considered were to occur simultaneously, new capital of up to $€ 2.9$ billion would be required. However, these shocks were fairly mild compared to the program projections made in May 2010, and as noted, the program assumed a quick recovery in growth that appeared optimistic. The $€ 10$ billion set aside for recapitalization under

\begin{tabular}{|lcc|}
\hline \multicolumn{3}{|c|}{$\begin{array}{c}\text { Stress Tests of Greek Banking System } \\
\text { (Percent, unless otherwise indicated) }\end{array}$} \\
\hline & $\begin{array}{c}\text { Article IV Adverse } \\
\text { Scenario, June, 2009 }\end{array}$ & $\begin{array}{c}\text { Program Projections, } \\
\text { May, 2010 }\end{array}$ \\
\hline Macro-scenarios & -3.0 & -6.6 \\
GDP contraction 1/ & +4.0 & +7.0 \\
Unemployment 2/ & $\approx 9.0$ & $\ldots$ \\
Long-term interest rates & 2.9 & Up to 10.0 \\
Estimated capital need (billions of euros) & & \\
\hline Source: IMF Country Report No. 09/244 & & \\
1/ Over 2 years. & & \\
2/ Compared to end-2008 level of 8 percent. & \\
\hline
\end{tabular}
the HFSF was thus all likely to be needed.

\section{H. Should debt restructuring have been attempted at the outset?}

53. The program was based on a number of ambitious assumptions. The preceding discussion has raised questions about whether the fiscal targets should have been less stringent and whether less optimistic projections should have been made about growth, deflation, privatization receipts, and regaining market access. Varying these assumptions would have materially affected the outlook for debt sustainability.

54. The risks were explicitly flagged. Staff made it clear that the program supported by the SBA was an ambitious program that was subject to considerable risks. The adjustment needs were huge, reforms would be socially painful, and commitment might flag. Debt was not judged to be sustainable with high probability and it would take little in the way of a deviation from program assumptions or an external shock to generate a less favorable debt trajectory. A combination of lower growth, greater deflation, higher interest rates, and larger contingent liabilities was shown to place public debt on a clearly unsustainable path (above 220 percent of GDP by 2020 and still rising). Since the shocks considered were fairly mild, this sensitivity analysis 
demonstrated the precariousness of the debt trajectory. For example, the deflation shock considered in the DSA (3 percent more) would not have made much difference to the internal devaluation, but would have caused debt to jump to 175 percent of GDP.

\section{Ex ante debt restructuring was not} attempted. One way to make the debt outlook more sustainable would have been to attempt to

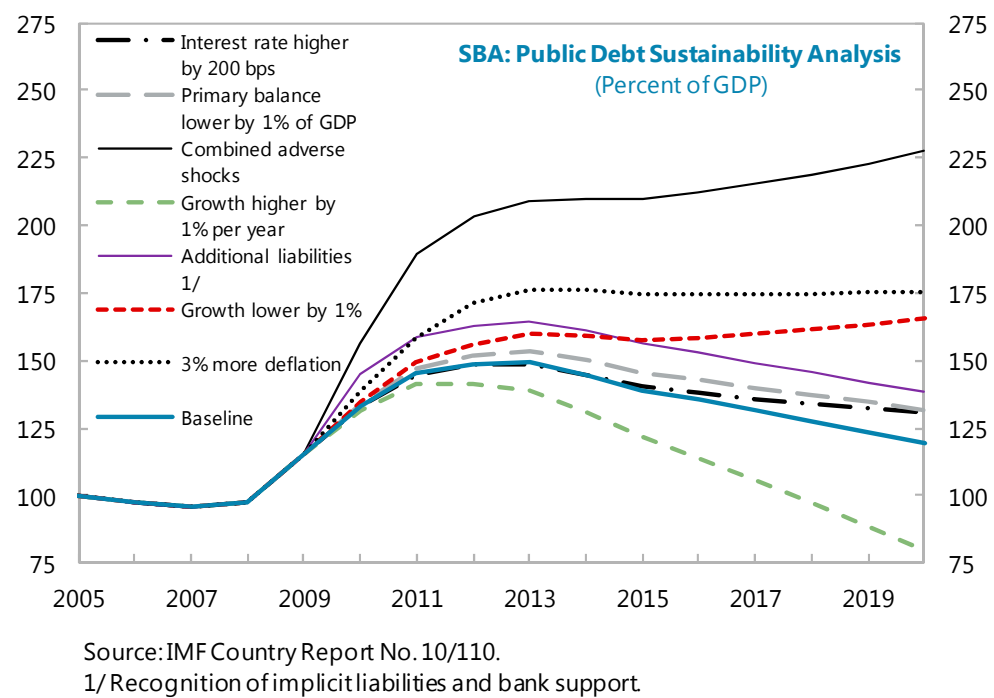
restructure the debt from the beginning. However, PSI was not part of the original program. This was in contrast with the Fund program in Uruguay in 2002 and Jamaica in 2011 where PSI was announced upfront. In Iceland in 2008, foreign creditors (albeit private bank depositors) were bailed in ex ante via capital controls, while Hungary, Latvia, and Romania, benefitted from the Vienna Initiative that was set up to encourage foreign banks to maintain credit lines. Yet in Greece, on the eve of the program, the authorities dismissed debt restructuring as a "red herring" that was off the table for the Greek government and had not been proposed by the Fund (Papaconstantinou, 2010). In fact, debt restructuring had been considered by the parties to the negotiations but had been ruled out by the euro area. There are a number of reasons for this:

- Some Eurozone partners emphasized moral hazard arguments against restructuring. A rescue package for Greece that incorporated debt restructuring would likely have difficulty being approved, as would be necessary, by all the euro area parliaments.

- Debt restructuring would directly hurt the balance sheets of Greek banks. This would imply a call on the program's financing that would exceed the amount set aside for bank recapitalization under the HFSF.

- Debt restructuring risked contagion to other members of the Eurozone and potentially another Lehman-type event, yet the EFSF was not yet in place. European banks had large holdings of Greek bonds - but also, and of more concern given the scale of their exposure, had large holdings of the bonds of other European sovereigns that would drop in value were Greek creditors to be bailed in. For the euro zone as a whole, there might be limited gain in bailing in creditors who subsequently might themselves have to be bailed out.

\section{Nonetheless, many commentators considered debt restructuring to be inevitable.}

With debt restructuring off the table, Greece faced two alternatives: default immediately, or move ahead as if debt restructuring could be avoided. The latter strategy was adopted, but in the event, this only served to delay debt restructuring and allowed many private creditors to escape. 
In fact, many observers at the time considered that the Greek program would not stave off debt rescheduling or a default. Commentators noted that the level of public debt would remain high and would be aggravated by the severe recession, while the nonconcessionary interest rates on official debt worsened the debt dynamics. ${ }^{17}$ In general, as evidenced by the behavior of bond spreads (see Box 1), markets were not convinced that the program would succeed. Statements by euro area leaders at Deauville in October 2010 that opened up the possibility of debt restructuring for Greece, contrary to its prohibition a few months earlier, also served to reinforce market doubts.

57. In the event, the SBA-supported program served as a holding operation. On the positive side, moving ahead with the Greek program gave the euro area time to build a firewall to protect other vulnerable members and averted potentially severe effects on the global economy. However, not tackling the public debt problem decisively at the outset or early in the program created uncertainty about the euro area's capacity to resolve the crisis and likely aggravated the contraction in output. ${ }^{18}$ An upfront debt restructuring would have been better for Greece although this was not acceptable to the euro partners. A delayed debt restructuring also provided a window for private creditors to reduce exposures and shift debt into official hands. As seen earlier, this shift occurred on a significant scale and limited the bail-in of creditors when PSI eventually took place, leaving taxpayers and the official sector on the hook.

\footnotetext{
${ }^{17}$ Notwithstanding approval of the program, the view that debt restructuring or default was inevitable in Greece was expressed in April-June 2010 by Ackerman, Goodhart, Kirkegaard, Lachman, Münchau, Rajan, Roubini, Sapir and Pisani-Ferry, Soros, Vines, and Wolf (all 2010). Buiter (2010) concluded that debt would need to be restructured because of the nonconcessional terms of the official lending. Mussa (2010) was unsure whether a restructuring would ultimately be necessary but gave it more than 50 percent chance. In other commentary, El Erian (2010) questioned whether the program had sufficient ownership given that there were few signs that Greek society had accepted the need for austerity. A more optimistic view was expressed by Moody's (2010) who noted that the program eliminated the near-term risk of a liquidity driven default.

${ }^{18}$ The recent paper on sovereign debt restructuring argues that delay in resolving an unsustainable debt situation serves to depress investment and growth in the debtor country and prolong financial uncertainty (see IMF, 2013).
} 


\section{CONSISTENCY WITH FUND RULES AND PRACTICES}

\section{A. Was exceptional access justified?}

\section{The justification for exceptional access criteria and the adequacy of access levels} require assessment. Exceptional access in the GRA constitutes levels beyond an annual limit of 200 percent of quota; and a cumulative limit of 600 percent of quota, net of rescheduled repurchases. Greece's access during the first year of the SBA would amount to 1,550 percent of quota and access was expected to peak at 3,212 percent of quota in April 2013. While these levels were unprecedented, they were dwarfed by Greece's public sector financing requirement. Moreover, the Fund's commitment was only 30 percent of the official financing and lower access would have limited the Fund's leverage. The exceptional access criteria apply at each review and should be assessed accordingly:

\section{Criterion 1 (exceptional balance of payments pressures on the current or capital account)} was satisfied at each stage of the program.

Criterion 2 (high probability of public debt being sustainable in the medium term) was not satisfied. As part of the summing up of the Board taken at the Greece SBA Board meeting, Criterion 2 was modified so that an exception would henceforth be made to the requirement that debt had to be judged to be sustainable with high probability in cases such as Greece where there was a high risk of international spillover effects. The systemic exception seems to have continued to be justified at each review, although the risks of contagion declined somewhat as more Greek government debt shifted to official hands.

Criterion 3 (good prospects of regaining access to private capital markets) was judged to be met. The Fund noted that successful implementation of the program and undertakings by Greece's euro area partners to stand ready to provide additional financial assistance would help address market uncertainty and facilitate the regaining of market access. However, additional financing assurances were not strong. Key partner country authorities made some promises to corral their national banks into maintaining credit lines and debt exposures, but (as they themselves predicted) these efforts had limited effect.

\section{Criterion 4 (a reasonably strong prospect of the program's success taking into account} institutional and political capacity to deliver adjustment) was also considered to be met. As discussed earlier, despite Greece's mixed record of reform in the past, the Fund drew comfort from a number of factors: (i) the program was backed at the highest political levels in Greece and Europe; (ii) the most difficult actions having been taken as prior actions; and (iii) the support that TA would provide to Greece's adjustment efforts. In the event, none of these factors proved to be compelling and ownership of the program in Greece was considerably overestimated.

The program went ahead with only Criterion 2 being modified. In the event, the judgments underlying both Criteria 3 and 4 proved to be too optimistic and with the benefit of hindsight, it is debatable whether these criteria were met at the time. 
59. The program request met Fund policies on financing assurances but those weakened significantly as the program unfolded. The Fund needs to be satisfied at each review that (i) the member has secured firm financing commitments to implement the intended policies, at a minimum, for a period of 12 months and (ii) there are good prospects for full financing until the end of the program. Conditional on the program's macroeconomic framework, the European financial commitment under the Greek Loan Facility met (i) and (ii). However, when outcomes deviated significantly from program assumptions, no new financing was committed and projected privatization receipts increased substantially, casting doubts on whether prospects for full financing until the end of the program were strong enough. ${ }^{19}$

\section{B. Was the SBA consistent with other Fund programs with countries in currency unions?}

60. The troika arrangement was unusual. The challenge faced by the Fund in dealing with Greece was how to square its dealings with a currency union that constitutes the second largest global economic bloc while maintaining equality of treatment for all Fund members (see PisaniFerry et al, 2011). Greece, however, was something of a special case. The Fund has had programs with members of currency unions in the past (ECCU, CFA franc), but none where the member country was systemic. A feature of the SBA-supported program was that there was no conditionality on areas within the competency of the currency union's central bank: however, during the course of the SBA, the ECB provided significant liquidity support to Greece and it is difficult to argue that an implicit or explicit agreement negotiated as part of the program would have required the ECB to have done more than this.

61. Nonetheless, the arrangement posed problems for program design. The Fund was required to negotiate first with the euro area countries (represented by the EC and ECB) and then with the Greek authorities. This had the advantage that the program would enjoy the necessary broader European support and that it would be consistent with euro area rules and norms. However, the Greek program was also subject to considerable uncertainty as the euro area policy response evolved. For example, the initial euro area position that debt restructuring was off the table was eventually reversed, although this took a considerable length of time. Similarly, there was an extended process before euro partners reached agreement on relaxing the fiscal stance.

\footnotetext{
${ }^{19}$ In the case of Iraq in 2004, for example, the Fund noted that while external debt was unsustainable, the risks from lending were mitigated by assurances received from the official bilateral creditors. In particular, the bulk of Iraq's official bilateral creditors through their Executive Directors reaffirmed their recognition of the Fund's preferred creditor status in respect of the drawings by Iraq, and indicated their willingness to use their best efforts to provide debt relief on appropriate terms to ensure the timely repayment to the Fund. In Greece's case, financing assurances have been strengthened under the EFF: euro area zone members have committed to supporting Greece for as long as it takes and have undertaken to reduce debt below 110 percent of GDP by 2020 providing that Greece continues to implement its adjustment program (IMF Country Report No. 13/20).
} 


\section{How well did the Troika arrangement work?}

62. There was no clear division of labor. Fund collaboration with the World Bank on country programs rests on an agreed division of labor. There was no such clarity in the assignment of responsibilities across the Troika. The EC needed to be involved in all aspects of the program to ensure conformity with European laws and regulations. While the Fund had experience designing fiscal adjustment, the EC had its own fiscal targets from Maastricht. The EC had structural reforms expertise, but so too did the Fund, particularly in the fiscal area. And from the Fund's perspective, the EC, with the focus of its reforms more on compliance with EU norms than on growth impact, was not able to contribute much to identifying growth enhancing structural reforms. In the financial sector, the ECB had an obvious claim to take the lead, but was not expert in bank supervision where the Fund had specialist knowledge.

63. Areas of expertise and experience differed within the Troika. The European institutions brought an integrated view to studying the Greek economy and emphasized the extent of possible spillover effects within Europe. At least initially, this was not the perspective taken by the Fund which was more accustomed to analyzing issues with a specific country focus. ${ }^{20}$ However, the EC tended to draw up policy positions by consensus, had enjoyed limited success with implementing conditionality under the Stability and Growth Pact, and had no experience with crisis management. The Fund's program experience and ability to move rapidly in formulating policy recommendations were skills that the European institutions lacked.

64. None of the partners seemed to view the arrangement as ideal. There were occasionally marked differences of view within the Troika, particularly with regard to the growth projections. However, the Troika in general seems to have pre-bargained positions so that differences were not on display to the authorities and did not risk slowing the program negotiations. The three institutions also have different internal procedures and the program documentation is voluminous, overlapping, and subject to varying degrees of secrecy. Nonetheless, coordination seems to have been quite good under the circumstances.

\section{Should the EFF have been introduced at the beginning?}

65. The three-year period of the SBA seemed relatively short. Given that the Greek program had so large a structural component, the question arises as to whether the arrangement should have been an EFF from the outset. However, while exceptional access has always been legally available under an extended arrangement, the Board as a policy matter had until the Ireland case expressed disfavor about using EFF resources as a means of providing exceptional

\footnotetext{
${ }^{20}$ This is consistent with Pisani-Ferry et al (2011) who in a study commissioned by the Fund as part of the Triennial Surveillance Review found insufficient integration in Fund surveillance between national and euro areawide analysis, particularly with regard to identifying spillovers between countries.
} 
access. In addition, the Board had generally viewed the EFF as a facility that should be used only by LICs. At the time, there was also the issue of whether the European partners were prepared to provide the longer-term financing that is a feature of EFF terms (as the Fund would not want to be the last creditor standing). Conversion of SBA into EFF was considered as early as a few months into the program but this was deferred pending consensus with the euro partners on a similar lengthening of their lending terms and until there was consensus on PSI.

\section{POSSIBLE LESSONS}

\section{This report concurs with the justifications that were presented for Greece's}

exceptional access SBA. The Fund approved an exceptionally large loan to Greece under an SBA in May 2010 despite having considerable misgivings about Greece's debt sustainability. The decision required the Fund to depart from its established rules on exceptional access. However, Greece came late to the Fund and the time available to negotiate the program was short. The euro partners had ruled out debt restructuring and were unwilling to provide additional financing assurances. The Fund was alert to the considerable dangers for the euro area and the global economy should Greece have been allowed to default. As the figure (adapted from the October 2012 GFSR) shows, the dislocation caused by the Lehman crisis was still recent and a renewed climate of fear in global markets had begun to

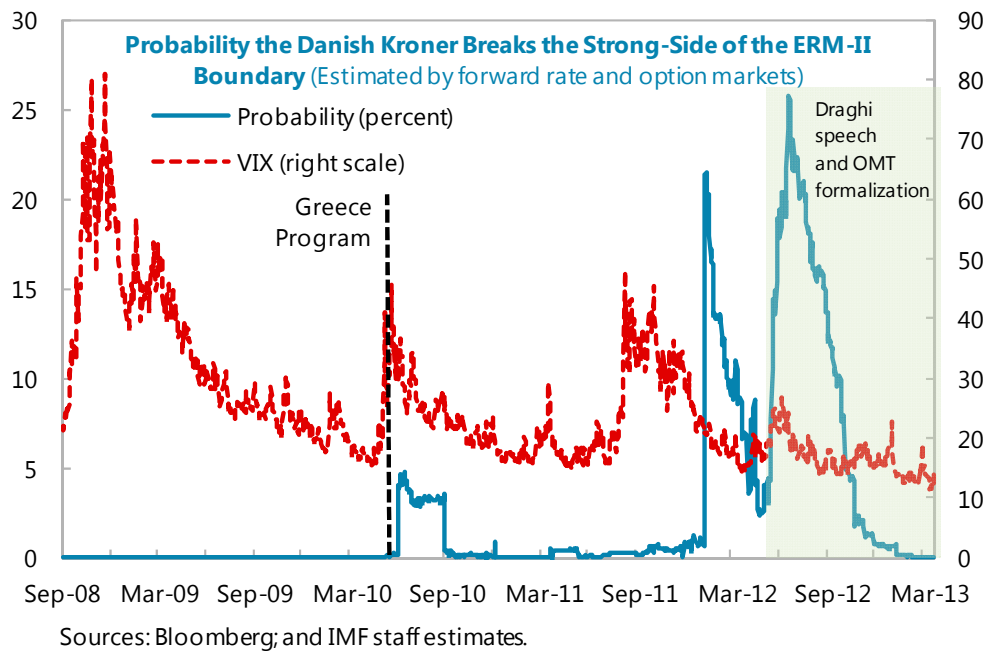
emerge in May 2010. In the view of the report, this unique environment justified the provision of an exceptional access SBA to Greece.

67. The report does not question the overall thrust of policies adopted under the SBAsupported program. Fiscal adjustment was unavoidable, as was the sharp pace of deficit reduction given that official financing was already at the limit of political feasibility and debt restructuring was initially ruled out. Structural reforms were clearly essential to restoring competitiveness. Some questions can be raised about the types of measures (overly reliant on tax increases) and structural conditionality (too detailed in the fiscal area), but the policies adopted under the program appear to have been broadly correct.

68. Nonetheless, there are possible lessons to be learned. The SBA-supported program avoided a disorderly default and limited euro-wide contagion. Greece has also been able to remain in the euro, but the recession has been deep with exceptionally high unemployment. The program did not restore growth and regain market access as it had set out to do. Major 
contributory factors to this lack of success were poor implementation of reform by the authorities, adverse political developments, and inconsistent policy signals by euro leaders. However, Greece's experience also carries lessons for Fund program design and surveillance regarding the need for:

- Better tailoring of Fund lending policies to the circumstances of monetary unions. Given the danger of contagion, there was a need to support Greece, but the Fund was worried that debt was not sustainable with high probability. In response, the exceptional access criterion was amended to lower the bar for debt sustainability in systemic cases. The baseline still showed debt to be sustainable, as is required for all Fund programs. However, the Fund emphasized the considerable risks that surrounded the baseline: growth could be lower, reforms might flag, deflation could be more severe, additional liabilities could appear. All these risks were to the downside. In the event, macro outcomes were far below the baseline and while some of this was due to exogenous factors, the baseline macro projections can be criticized for being overly optimistic.

However, advantage could not be taken in the design of the program of one of the country's major strengths, namely the support that Greece might ultimately receive from its euro area partners if it could demonstrate a sufficient track-record of program implementation. Adjusting lending policies to the particular circumstances of monetary unions might allow the possibility of such conditional future assistance to be recognized in program agreements. To some extent this approach is being followed in the EFF-supported program, with euro area partners indicating a willingness to provide additional financing and debt relief conditional on Greece continuing to implement the program.

Lending policies for countries in monetary unions also need to be sensitive to the large structural component of programs when exchange rates are fixed. In this context, the Fund arrangement for Greece should ideally have been an EFF from the outset. More generally, the case for refining the Fund's policies and framework for lending to members of currency unions needs to be explored.

- Avoiding undue delays in debt restructuring. Upfront debt restructuring was not feasible at the outset. While the Fund began to push for PSI once the program went off track in early 2011, it took time for stakeholders to agree on a common and coherent strategy. Earlier debt restructuring could have eased the burden of adjustment on Greece and contributed to a less dramatic contraction in output. The delay provided a window for private creditors to reduce exposures and shift debt into official hands. This shift occurred on a significant scale and left the official sector on the hook.

- More attention to the political economy of adjustment. Reform efforts in Greece under the program might have been more enduring if more visible progress had been made with regard to getting those on high incomes to pay their taxes. The program made an attempt to reflect distributional concerns by shielding those on low incomes from cuts in state pensions. 
The risks to public support for the program from not reducing tax evasion were also continually flagged by the Fund. The lack of political will to make clear progress with improving tax compliance was nonetheless a considerable obstacle to the program's success.

The Greek program also provides further evidence that the success of a program hinges centrally on the depth of its ownership. While a bipartisan agreement with the opposition was probably not possible in May 2010, the SBA-supported program attracted more bipartisan support over time including with the formation of a technocratic government in late 2011. However, significant opposition remained.

- More parsimony in fiscal structural reforms. The Fund's unprecedented TA programs in Greece, especially on revenue administration, may have gone beyond providing technical advice and taken on an institution building dimension. The detailed conditionality is considered macro-critical and essential given the large fiscal adjustment that is programmed and the dire need to strengthen Greek fiscal institutions. Moreover, the authorities seem to welcome the degree of Fund involvement, with no suggestion that it has become overlyintrusive. Nonetheless, these efforts are unlikely to be able to substitute for political ownership and the case for a more hands-off approach should be considered.

- More streamlining in the Troika process. A clear division of labor of responsibilities within the Troika is difficult given the overlapping responsibilities of the institutions. There are also synergies arising from cooperation in areas with shared expertise. Nevertheless, European institutions have comparative advantage in certain structural issues that are beyond the Fund's core areas of expertise. Options for dividing up work on areas that are not macrocritical should therefore be explored. There may also be some scope for streamlining procedures and documents to reduce the burden on the authorities.

- More effective risk-sharing arrangements within the euro area. The Greek crisis brought to the fore shortcomings in the euro area architecture related to risk sharing and crisis response. As argued elsewhere (see IMF, 2012b), the lack of fiscal risk sharing arrangements or a true banking union within the euro area makes individual member states vulnerable to sovereign debt crises that could spill over to banking systems (or be caused by banking crises) and the real economy, without exchange rate flexibility or independent monetary policy to help with the adjustment. The euro area member states have gradually responded to the crisis in Greece and elsewhere by establishing firewalls (EFSF, ESM, and OMT) and taking steps towards a banking union, as well as strengthening fiscal rules to reduce vulnerabilities. 


\section{Box 1. A Chronology of Events}

- Initial improvements in sentiment dissipated after a ratings downgrade in June 2010, but spreads tightened again with the successful completion of the first review in September.

- However, there was an adverse market reaction to statements by euro leaders at Deauville in October 2010 that set off a public debate on the need for debt restructuring and PSI.

- Sentiment deteriorated further in November when the estimated 2009 fiscal deficit was revised from 131/2 to $15 \frac{1}{2}$ percent of GDP, and in December when there were general strikes and rioting in response to the labor reforms.

- The second review of the program was completed in December 2010, but by the third review in February 2011 , problems in program implementation were becoming apparent. The weak economy was making fiscal adjustment more difficult and the debt sustainability looked increasingly uncertain. Efforts were made to bring the program back on track during 2011, including ambitious privatization plans. The need for PSI was acknowledged by the fourth review in July 2011.

- As 2011 progressed, a Greek euro exit became a serious possibility particularly after being discussed by Euro leaders at the Cannes summit in November 2011.

- The government then announced a referendum to test the views of the Greek people. This was subsequently cancelled, but the government resigned later that month and was replaced by a technocratic government.

- The SBA was cancelled and replaced with a new program supported by an EFF in March 2012. Sentiment subsequently turned around once the PSI came into effect. Actions by the ECB in 2012 were also extremely supportive.

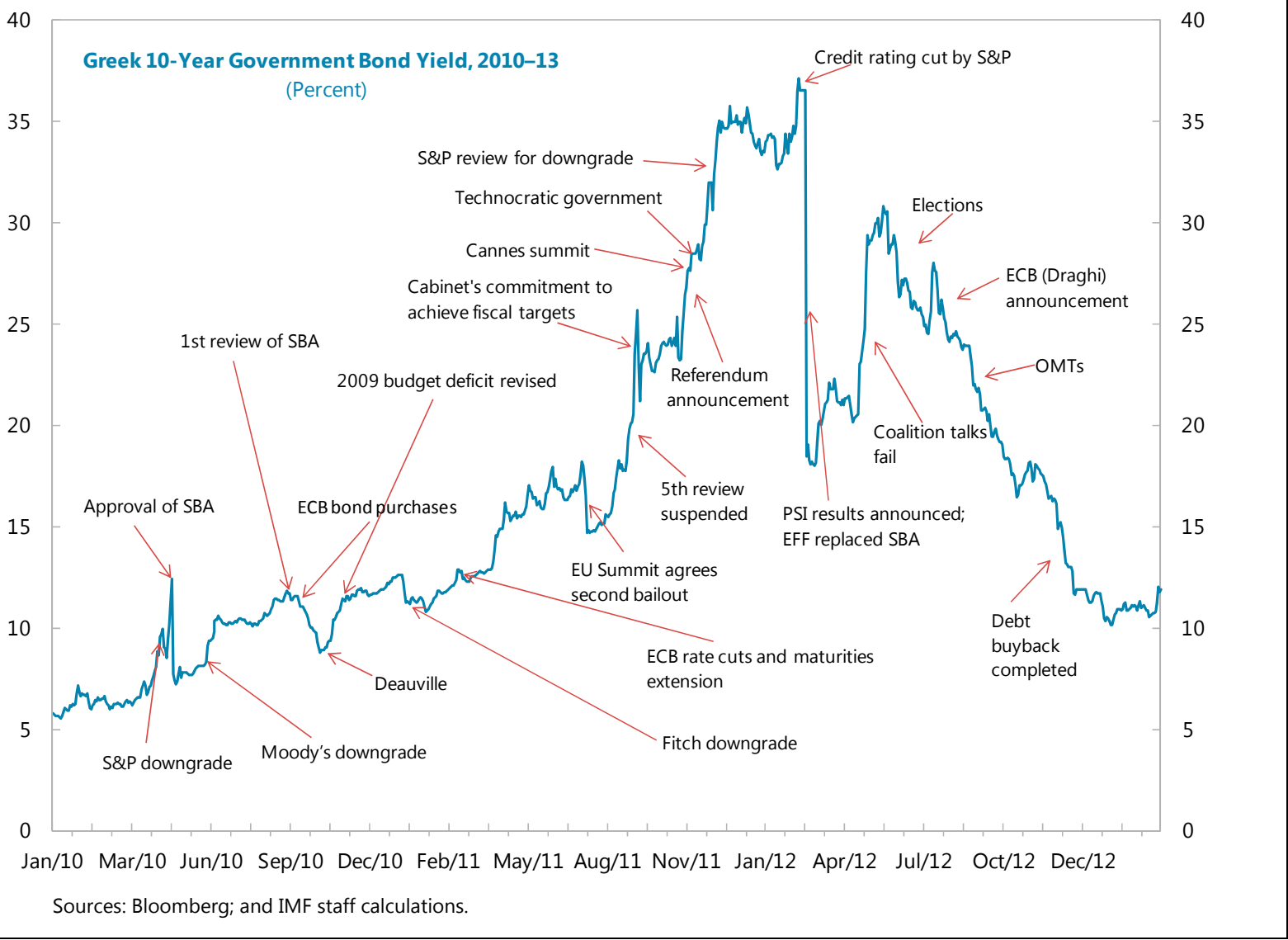


Box 2. Progress with Internal Devaluation under the SBA-Supported Program

Greece began the program with large price and wage competitiveness gaps due to rapid growth of labor costs and market inefficiencies. To improve competitiveness, the program initiated a comprehensive agenda of structural reforms that included reducing public sector wages; liberalizing wage-setting and loosening employment restrictions in the private sector; improving the business environment by cutting red tape; and reducing barriers to entry and market distortions in protected industries. The program began with some deregulation (fast-track investment and one-stop shop legislation), but labor market reforms were not initially deep enough to tackle entrenched labor market inflexibility.

Unit labor costs declined significantly during the program period. In real terms, the ULC-based real effective exchange rate depreciated by 9 percent from May 2010 to March 2012. The major part of the improvement in competitiveness was due to wage reductions associated with the intense recession. There were limited gains in productivity (see Kang and Shambaugh, 2013).
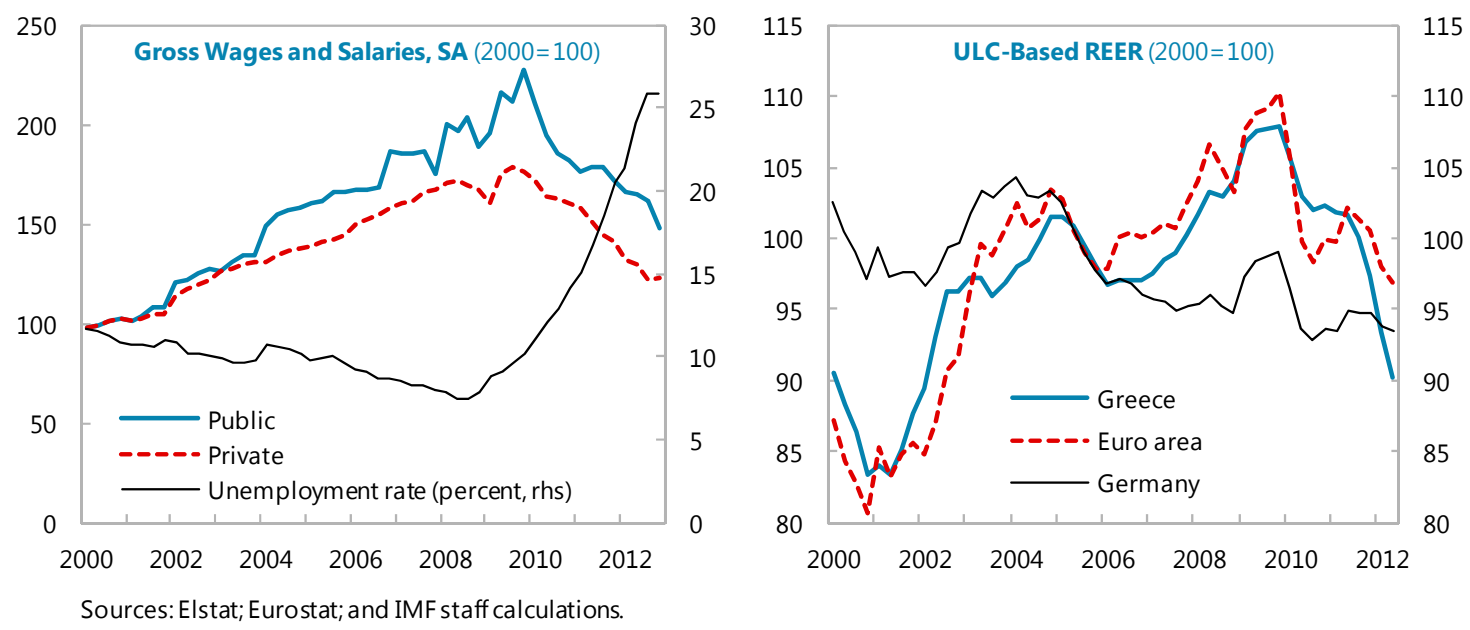

Prices have not been as flexible as wages. The CPIbased REER has a degree of upward bias as it does not discount tax increases implemented in 2010 or take into account changes in trade weights due to the redirection of exports towards emerging markets since 2009. Nevertheless, during the period of the SBA, the CPI-based real effective exchange rate depreciated by only 3 percent.

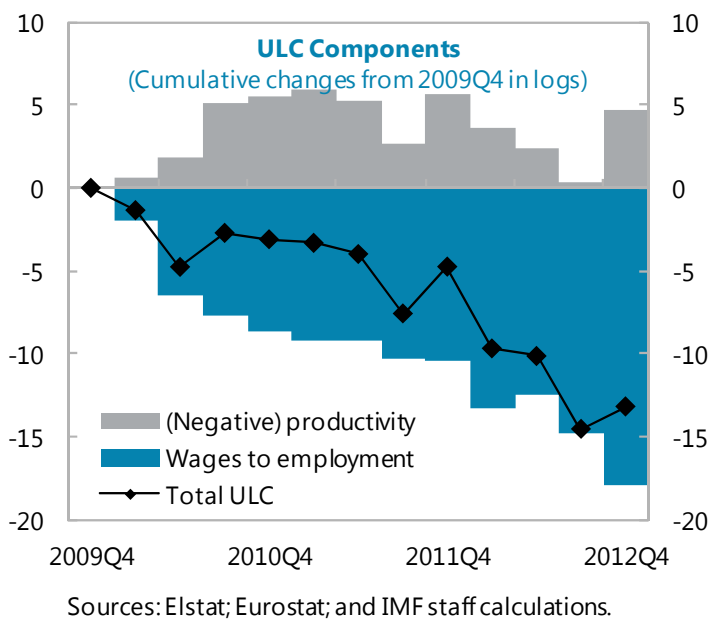




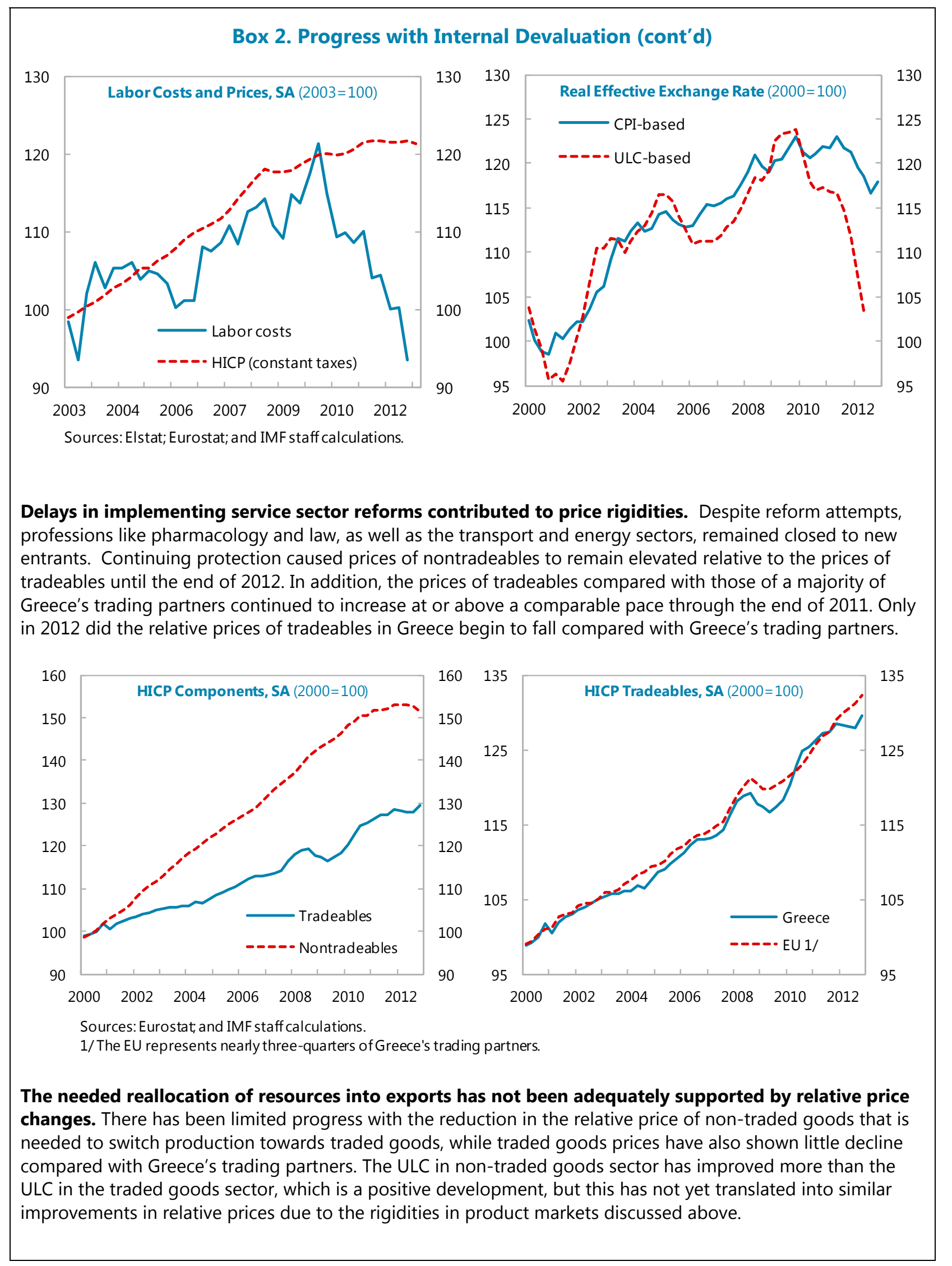




\section{Box 3. Pension Reform}

Pension outlays were high before the crisis and their projected trajectory worrisome. At 16 percent of GDP, pension spending in Greece was among the highest in the EU in 2010. Key pension indicators suggested a generous system: the replacement rate (pension-to-wages) was 57 percent, the third highest in EU; the dependency rate (pensioners-to-contributors) was 29 percent, above the EU average; the official retirement age was 60 , well below the OECD average of 63.2, and the average pension (including all pensions) was very close in level to that of a typical German worker with full contribution history. Pension projections pointed to a solvency problem.

Generous pension and wage increases and a worsening demographic profile were the main culprits behind the unfavorable long-term pension profile. The decade before the crisis witnessed real pension increases as well as substantial wage increases that also pushed up pensions. Numerous loopholes allowed early retirement contributing to an already high growth of pensioners. Pension spending increased by almost 5 percentage points of GDP from 2001 to 2008, outpacing other EU countries.

Other shortcomings of the system were also important. Early retirement incentives for low-income workers and high statutory replacement rates, inadequate IT and accounting systems, fragmented retirement regimes, and low compliance with contributions were some of the features of the pension system that created economic distortions and generated leakages, swelling deficits beyond sustainability.

The pension reform under the SBA-supported program tackled multiple deficiencies to bring about a sustainable long-term pension profile. Following the frontloaded pension cuts at the onset of the program, the new (PAYG) system was designed to top up the existing non-contributory social pension. The retirement age was set at 65 years and indexed to life expectancy; the base wage for the calculation of pensions became tied to lifetime wage history rather than the final five years; accrual rates were lowered, and pensions indexed to prices and GDP growth (whatever was the lowest). Other changes included harmonization of rules across funds and rationalization of the number of funds. Control mechanisms were enhanced by mandating exclusive payment of pensions through banks, and requiring periodic pension audits, monitoring of funds' finances and periodic actuarial analysis. ${ }^{1}$

\begin{tabular}{|lcc|}
\hline \multicolumn{3}{|c|}{ Pension System Parameters } \\
\hline Reform elements & Before Reform & After Reform \\
\hline Accrual rate & $2-3 \%$ & $0.8-1.5 \%$ \\
Replacement rate & $70 \%$ & $60 \%$ \\
Retirement age & 60 & 65 \\
Early retirement age & $<60$ & 60 \\
Pensions base calculation & Last 5 years & Lifetime \\
& earnings & earnings \\
Indexation of pensions & Policy decision & CPI and GDP \\
Annual deficit in 2060 & $12.5 \%$ & $2.5 \%$ \\
\hline \multicolumn{2}{|c|}{ Sources: OECD; and IMF staff estimates. } \\
\hline
\end{tabular}

The second stage reforms focused on deficits in supplementary and lump sum accounts and on poorly targeted social benefits. Following the pension cuts and the passage of the new law, it became clear that social spending remained high and further reforms were needed. Some of the subsequent reforms under the MTFS began tackling the still complex institutional structure, as well as the abuse of benefits, their unequal distribution, and ineffective targeting.

The pension reform was one of the main achievements of the SBA-supported program. The reform was approved in July 2010 amid widespread social discontent with austerity measures. Because the authorities wanted to accelerate the implementation, the reform was not preceded by a proper actuarial study (a structural benchmark under the program), and the public was not made fully aware of the need for reform early in the program. The reform was nonetheless essential to restoring the sustainability of the pension system - a significant achievement - although implementation risks remain. Moreover, the reform only addressed long-term structural imbalances whereas the immediate fiscal pressures on the social security system were tackled separately as part of the fiscal consolidation including by eliminating pension bonuses.

${ }^{1}$ The pension law also included institutional reforms in the health sector providing for the financial accounting independence of health funds and integration of social security funds with the NHS. 


\section{Box 4. Revenue Administration Reform during the SBA-Supported Program}

Low revenue efficiency has been a chronic problem for Greece. The efficiency index of VAT collections, for example, is below average for European countries. ${ }^{1}$ Similarly, collections of personal income tax are substantially lower compared to the euro area countries, despite comparable statutory tax rates. This reflects various reasons, including institutional weaknesses of revenue administration, a large size of informal economy, a highly complex tax system with myriad preferential tax treatment and exemptions, and a large share of self-employed individuals in the business sector (OECD, 2011).

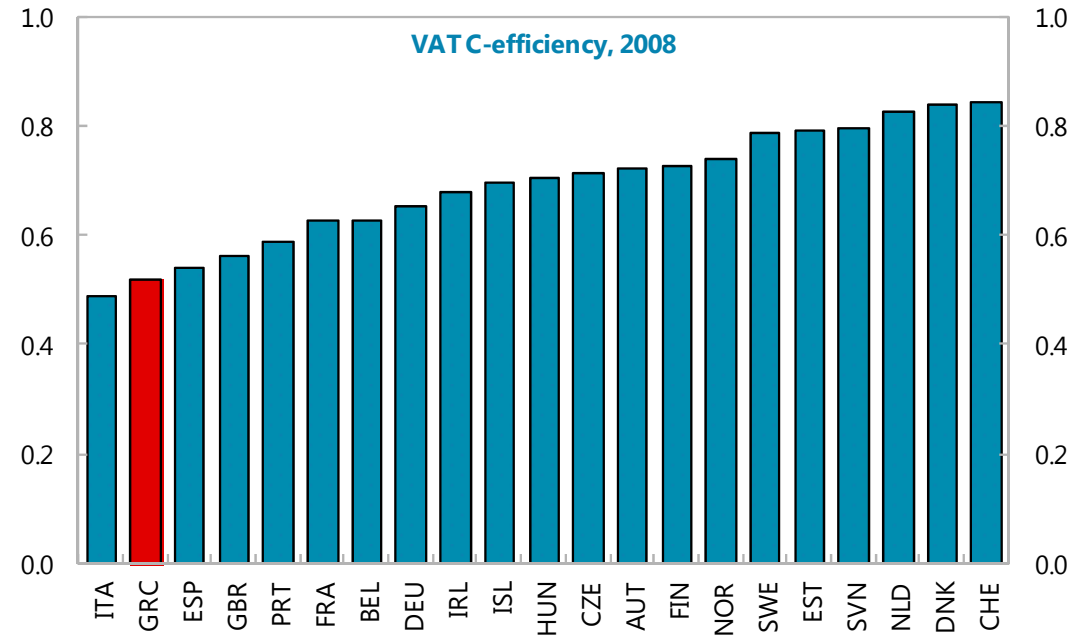

Sources: Eurostat, and IMF staff calculations.

Revenue administration reform was embedded in the structural reform agenda of the program. At the beginning of the program, the authorities adopted a reform strategy that consisted of intensified anti-evasion actions against targeted taxpayers, as well as a medium-term reform plan to modernize revenue administration. In line with this, the SBA established a limited number of structural benchmarks: set up taskforces to implement the anti-evasion actions (by September 2010); table legislations to remove various obstacles for revenue administration (by February 2011); articulate a medium-term reform plan (by June 2011); and achieve quantitative performance targets (by December 2011). The design of the initial strategy and reform process throughout the SBA were supported by intensive technical assistance from the Fund, which included installment of a long-term residential advisor and peripatetic expert visits. The implementation of the benchmarks was broadly satisfactory: the first three structural benchmarks were implemented broadly as scheduled, ${ }^{2}$ and the quantitative performance targets were met except for audits of large taxpayers.

\begin{tabular}{|c|c|c|c|}
\hline \multicolumn{4}{|c|}{ Key Performance Indicators of Tax Administration, December, 2011 1/ } \\
\hline Indicator & Actual & Target & Met / Not Met \\
\hline \multicolumn{4}{|l|}{ Debt collection } \\
\hline Pre-2011 debt collected (millions of euros) & 946 & 400 & Met \\
\hline \multicolumn{4}{|l|}{ Audits of large taxpayers } \\
\hline Number of completed full-scope audits & 44 & 75 & Not met 2/ \\
\hline Assessted taxes collected (percent) & 66.5 & $20 / 303 /$ & Met \\
\hline \multicolumn{4}{|l|}{ Audits of wealthy and high income taxpayers } \\
\hline Number of completed audits & 404 & 400 & Met \\
\hline Assessed taxes collected (percent) & 47.3 & $20 / 303 /$ & Met \\
\hline \multicolumn{4}{|l|}{ VAT audits of non-filers } \\
\hline Number of completed audits & 22,235 & 1,000 & Met \\
\hline \multicolumn{4}{|l|}{ Sources: Ministry of Finance; and IMF staff estimates. } \\
\hline \multicolumn{4}{|c|}{ 1/ Meeting these targets was an end-2011 structural benchmark under the 2010 SBA. } \\
\hline \multicolumn{4}{|c|}{ 2/ This target was reset as a prior action for the 2012 EFF and met by February, 2012.} \\
\hline \multicolumn{4}{|c|}{$\begin{array}{l}\text { 3/ } 20 \text { percent of all assessed taxes and penalties from new audits within } 3 \text { months of assessment, and } \\
\text { collection of } 30 \text { percent of all taxes and penalties from new audits within } 6 \text { months of assessment date. }\end{array}$} \\
\hline
\end{tabular}

\footnotetext{
${ }^{1}$ The VAT C-efficiency is the ratio of VAT collections to the product of the standard VAT rate and aggregate consumption. In the absence of exemptions, zero-rating (other than exports) and zero registration threshold, and no revenue leakage due to tax administration and informality factors, the $\mathrm{C}$-efficiency ratio is, by construction, equal to one.

${ }^{2}$ The benchmark to table legislations to remove obstacles was completed as prior action for the $3^{\text {rd }}$ review in March 2011.
} 


\section{Box 4. Revenue Administration Reform (cont.)}

Although program benchmarks were met, improving tax administration proved to be considerably more complex and time-consuming than expected. Looking at outcomes, the C-efficiency indicator deteriorated in 2011, and the VAT rate increases in 2010 did not bring about a higher ratio of VAT collections to GDP. While this could be due to behavioral changes of consumers (i.e., demand shifted towards goods with preferential VAT rates), it may also reflect worsened tax compliance. Indeed, the government's anti-evasion policies do not appear to have become fully operational. For example, basic operational functions such as audits and debt collections, as well as the newly established large taxpayer unit, remained severely understaffed. The achievement of quantitative indicators did not fully reflect permanent improvements in business practices; in particular, the target for audits of wealthy taxpayers was met largely due to temporary incentives to taxpayers.

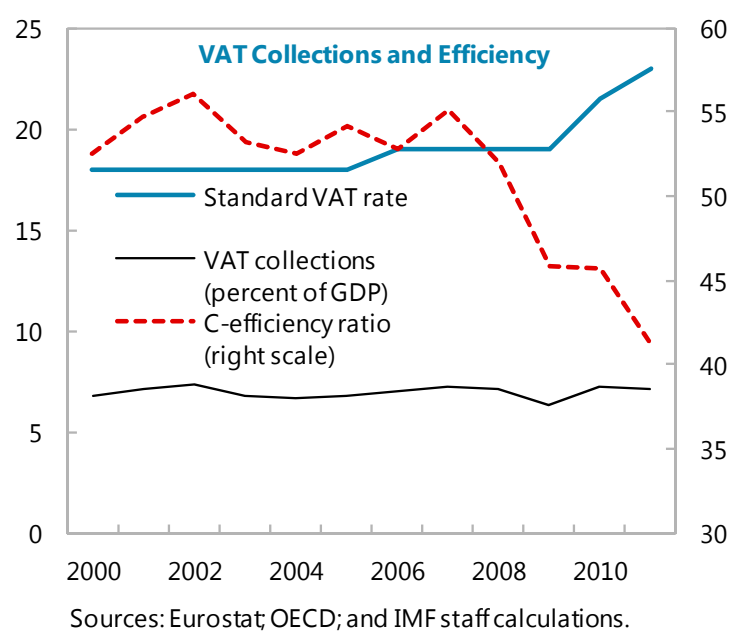

The unsatisfactory progress reflects a mix of factors, including deep-rooted structural problems, worsened economic conditions, and limited ownership by the authorities. Resolving fundamental issues such as the existence of the large informal economy, the complex tax system, and the limited capacity of revenue administrators takes time. Moreover, deterioration in economic and political conditions during the crisis severely hampered anti-evasion efforts. On the other hand, the unsatisfactory progress with making reform plans functional points to limited ownership. Review by the Fund and the EC staff pointed to a lack of full political commitment to reform, absence of leadership, and continued internal resistance to reform as underlying reasons behind these developments. In hindsight, the structural benchmarks could have been more effective if the authorities had been willing to address fundamental institutional issues (e.g., increase autonomy by revamping the governance and organization structure) as well as operational aspects (e.g., ensure appropriate resource allocations to key administration functions).

Reference: OECD, 2011, "OECD Economic Surveys: Greece 2011," OECD Publishing. http://dx.doi.org/10.1787/eco surveys-grc-2011-en 


\section{Box 5. Structural Benchmarks: Design and Implementation}

Structural Benchmarks (SBs) focused heavily on fiscal reforms. SBs were established in the area of pensions, tax administration, public financial management, debt management, sub-national government rationalization, and government wage and employment control. Reforms were supported by extensive Fund technical assistance.

\section{Competitiveness reforms flowed from the EC's agenda.}

Conditionality encompassed labor markets, the transport, retail, energy, and tourism sectors, and the overall business environment. The SBA request contained only one SB related to competitiveness: the preparation of a privatization plan. The second review set an SB on reforming the collective bargaining system and the third review set one on repealing closed professions. There were numerous competiveness-related SBs in the fourth and fifth reviews. In the financial sector,

establishment of the Hellenic Financial Stability Fund was an initial SB.

The total number of SBs was relatively large. The number of SBs was larger than in comparator programs (see "2011 Review of Conditionality Overview Paper", 2012, Policy Paper and Figure 2). However, the heavy fiscal structural conditionality was a response to Greece's weak administrative capacity, while the need for competitive-promoting reforms appears higher in a case like Greece that lacks an exchange rate tool.

\section{Compliance with fiscal SBs was initially good, but} implementation proved difficult. Up to the third review most fiscal SBs were met on time. However, the initial focus was on changes in laws and plans that were relatively easy to achieve. Limited progress was made in checking tax evasion and making the tax burden more equitable, potentially fanning public opposition to the program. There was also a growing realization that the authorities had limited capacity to implement changes on the ground and to counter resistance in the bureaucracy. The program thus began to focus increasingly on operational details, including organizational structures, audit practices, and dispute procedures that were leaving large tax debts uncollected. Performance indicators were developed to monitor progress under the tax evasion plan. By the fifth review, the content of fiscal SBs had become more detailed and encompassed multiple sub-conditions.

\section{Limited progress was also made with competitiveness-}

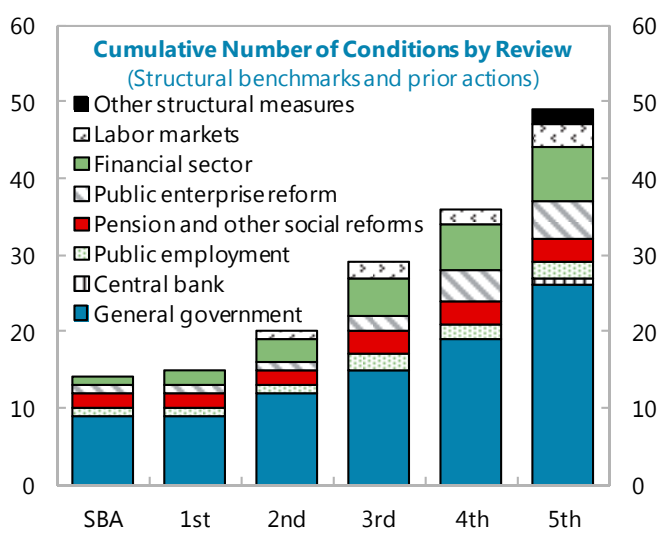

Source:IMF staffestimates.

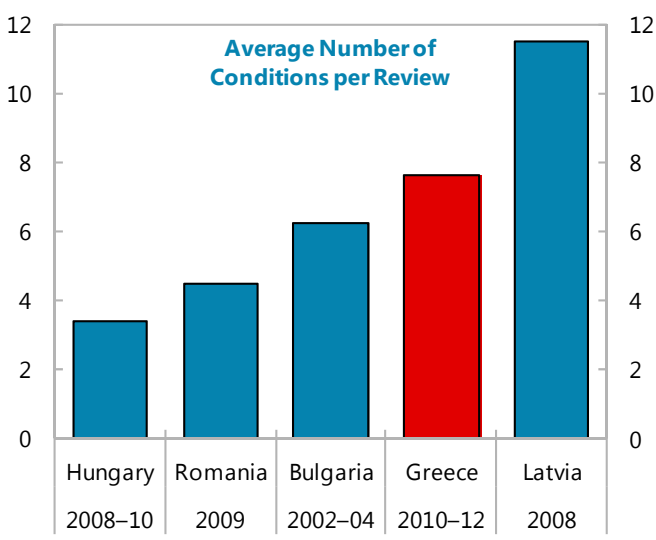

Source:IMF staff estimates.

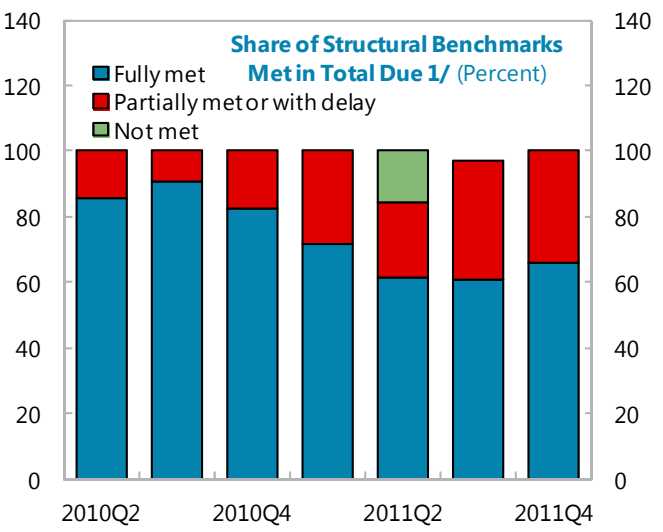

Source: IMF staff estimates.

1 / Cumulative number of structural benchmarks met out of structurual benchmarks due in the quarter.

promoting reforms. Despite meeting formal conditionality, structural reforms also failed to be implemented due to resistance by vested interests. Growth-enhancing structural reforms that were initially cast in general terms became more specific as implementation fell short. For example, the blanket legislation to liberalize closed professions was succeeded under the EFF-supported program by detailed legislative and regulatory changes needed on a profession by profession basis. 
Table 1. Greece: Selected Economic Indicators, 2009-14

\begin{tabular}{|c|c|c|c|c|c|c|c|}
\hline & \multirow[t]{2}{*}{2009} & \multirow[t]{2}{*}{2010} & \multirow[t]{2}{*}{2011} & \multicolumn{2}{|c|}{2012} & \multirow{2}{*}{$\frac{2013}{\text { Proj. }}$} & \multirow[t]{2}{*}{2014} \\
\hline & & & & Prog. & Est. & & \\
\hline & \multicolumn{7}{|c|}{ (Percentage change, unless otherwise indicated) } \\
\hline \multicolumn{8}{|l|}{ Domestic economy } \\
\hline Real GDP & -3.1 & -4.9 & -7.1 & -6.0 & -6.4 & -4.2 & 0.6 \\
\hline Output gap (percent of pot. output) & 7.3 & 3.3 & -2.6 & -7.3 & -7.7 & -10.6 & -9.5 \\
\hline Total domestic demand & -5.5 & -7.0 & -8.7 & -8.7 & -10.4 & -5.6 & -1.1 \\
\hline Private consumption & -1.6 & -6.2 & -7.7 & -7.7 & -9.1 & -6.9 & -1.6 \\
\hline Public consumption & 4.9 & -8.7 & -5.2 & -6.2 & -4.2 & -4.0 & -6.2 \\
\hline Gross fixed capital formation & -13.7 & -15.0 & -19.6 & -14.4 & -19.2 & -4.0 & 8.4 \\
\hline Change in stocks (contribution) & -1.2 & 0.7 & -0.4 & 0.4 & 0.0 & 0.4 & 0.0 \\
\hline Foreign balance (contribution) & 3.0 & 3.0 & 2.4 & 3.3 & 3.7 & 2.6 & 1.7 \\
\hline Exports of goods and services & -19.4 & 5.2 & 0.3 & -1.2 & -2.4 & 3.0 & 4.6 \\
\hline Imports of goods and services & -20.2 & -6.2 & -7.3 & -11.5 & -13.8 & -6.4 & -1.9 \\
\hline Unemployment rate (percent) $1 /$ & 9.4 & 12.5 & 17.5 & 24.4 & 24.2 & 27.0 & 26.0 \\
\hline Employment 1/ & -1.0 & -2.7 & -6.6 & -9.2 & -8.2 & -3.7 & 0.6 \\
\hline Unit labor costs & 4.2 & -2.6 & -4.3 & -8.1 & -4.2 & -7.0 & -1.5 \\
\hline Consumer prices (HICP), end of period & 2.6 & 5.2 & 2.4 & 1.3 & 0.8 & -0.6 & -0.1 \\
\hline Consumer prices (HICP), period average & 1.2 & 4.7 & 3.3 & 1.2 & 1.5 & -0.8 & -0.4 \\
\hline Core prices, period average $2 / 3$ / & 2.3 & 2.6 & 1.1 & $\ldots$ & -0.3 & 3.6 & $\ldots$ \\
\hline GDP deflator & 2.3 & 1.1 & 1.0 & -0.5 & -0.8 & -1.1 & -0.4 \\
\hline & \multicolumn{7}{|c|}{ (Percent of GDP, unless otherwise indicated) } \\
\hline \multicolumn{8}{|l|}{ Balance of payments } \\
\hline Current account & -11.2 & -10.1 & -9.9 & -4.2 & -3.4 & -0.8 & -0.2 \\
\hline Structural current account balance & -7.0 & -8.3 & -10.9 & $\ldots$ & -5.4 & -4.9 & -3.6 \\
\hline Trade balance & -7.8 & -6.8 & -6.0 & -2.5 & -2.5 & -0.2 & 55.2 \\
\hline Export of goods and services & 18.3 & 20.5 & 23.4 & 25.3 & 25.4 & 27.4 & 28.3 \\
\hline Imports of goods and services & -26.2 & -27.3 & -29.5 & -27.8 & -27.9 & -27.6 & -26.9 \\
\hline Total transfers & 0.6 & 0.1 & 0.3 & 0.3 & 0.7 & 1.8 & 1.5 \\
\hline Net income receipts & -3.9 & -3.5 & -4.1 & -2.0 & -1.6 & -2.5 & -3.1 \\
\hline Net international investment position & -86.4 & -98.4 & -86.1 & -94.2 & -114.1 & -118.9 & -117 \\
\hline \multicolumn{8}{|l|}{ Public finances (general government) } \\
\hline Total revenues & 38.3 & 40.6 & 42.4 & 43.6 & 44.1 & 44.3 & 43.7 \\
\hline Total expenditures & 54.0 & 51.4 & 52.0 & 50.3 & 50.4 & 48.4 & 46.9 \\
\hline Primary expenditures & 48.8 & 45.5 & 44.8 & 45.1 & 45.4 & 44.3 & 42.2 \\
\hline Overall balance & -15.6 & -10.8 & -9.6 & -6.7 & -6.3 & -4.1 & -3.3 \\
\hline Primary balance & -10.5 & -4.9 & -2.4 & -1.5 & -1.3 & 0.0 & 1.5 \\
\hline Gross debt & 130 & 148 & 170 & 158 & 157 & 176 & 174 \\
\hline \multicolumn{8}{|l|}{ Interest rates and credit } \\
\hline Lending interest rate (percent) 4/ & 5.1 & 6.1 & 6.8 & $\ldots$ & 5.8 & 5.8 & $\ldots$ \\
\hline Private credit growth (percent change) 5/ & 4.2 & 0.0 & -3.1 & -7.2 & -4.0 & -6.5 & -4.0 \\
\hline \multicolumn{8}{|l|}{ Exchange rates, end-period (percent change) 3 / } \\
\hline Nominal effective exchange rate & 0.4 & -3.7 & 0.0 & $\ldots$ & -0.5 & -0.6 & $\ldots$ \\
\hline Real effective exchange rate (CPI-based) & 1.7 & -1.2 & -0.7 & $\ldots$ & -1.9 & -0.9 & $\ldots$ \\
\hline Real effective exchange rate (man. ULC-based) & 1.1 & 0.8 & -6.1 & $\ldots$ & -8.4 & -8.4 & $\ldots$ \\
\hline \multicolumn{8}{|l|}{ Memorandum items: } \\
\hline Nominal GDP (billions of euros) & 231 & 222 & 209 & 195 & 194 & 183 & 184 \\
\hline Nominal GDP (percent change) & -0.9 & -3.9 & -6.1 & -6.5 & -7.1 & -5.3 & 0.2 \\
\hline
\end{tabular}

Sources: National Statistical Service; Ministry of Economy and Finance; Bank of Greece; and IMF staff projections.

1/ Based on Labor Force Survey.

2/ Core prices exclude energy, food, alcohol, and tobacco.

3/ Data for 2013 as of March.

4/ Data for 2013 as of February.

5/ Includes securitized or otherwise transferred loans from 2010 onward. 
Table 2. Greece: Quantitative Performance Criteria, 2010-13

(Billions of Euros)

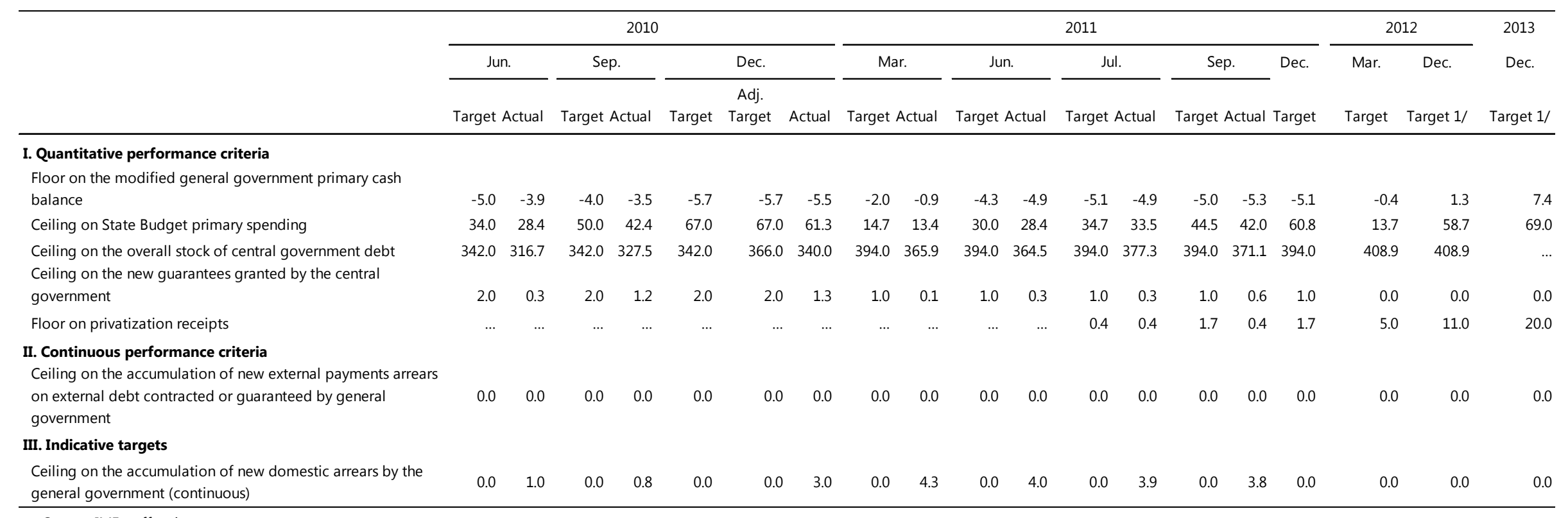

1/ Indicative. 
Table 3. Greece: Structural Conditionality

\begin{tabular}{lcc}
\hline \multicolumn{1}{c}{ Measures } & \multicolumn{1}{c}{ Date } & Target \\
\hline & & Status \\
\hline Prior actions and structural benchmarks & & \\
\hline Fiscal sector & Request & PA \\
$\begin{array}{l}\text { Reduce public wage bill by cutting bonuses/allowances; and pension bonuses (except } \\
\text { minimum pensions). }\end{array}$ & Request & PA \\
$\begin{array}{l}\text { Increase standard VAT rate from } 21 \text { to } 23 \text { percent and reduced rate from } 10 \text { to } 11 \text { percent and } \\
\text { excise tax rates on alcohol, tobacco, and fuel with a yield of at least } € 1.25 \text { billion in the } \\
\text { remainder of 2010. }\end{array}$ & Request & PA \\
$\begin{array}{l}\text { Appoint staff team and leader in GAO responsible for general government in-year cash } \\
\text { reporting. }\end{array}$ & Met \\
$\begin{array}{l}\text { Adopt and start to implement a reorganization of sub-central government with the aim to } \\
\text { reduce the number of local administrations and elected/appointed officials (Kalikrates). }\end{array}$ & Request Jun-10
\end{tabular}

Submit to parliament amendments to Law 2362/1995 to (i) require the MoF to present a threeyear fiscal and budget strategy, (ii) introduce topdown budgeting with expenditure ceilings for the State budget and multi-year contingency margins, (iv) require a supplementary budget for Request Jun-10 Met any overspending above the contingency, $(\mathrm{v})$ and introduce commitment controls. The amended law should be immediately effective, including in the context of the 2011 budget.

The National Actuarial Authority to produce a report to assess whether the parameters of the new system significantly strengthen long-term actuarial balance.

Request Jun-10 Met with

Request Sep-10 Met

Adopt a comprehensive pension reform that reduces the projected increase in public spending on pensions over the period $2010-60$ to $2 \frac{1}{2}$ percent of GDP.

Establish a commitment register in all line ministries and public law entities. Begin publishing monthly data on general government in-year fiscal developments (including arrears).

Publish 2009 financial statements of the ten largest loss-making public enterprises, audited by chartered accountants, on the official website of the Ministry of Finance.

Put in place an effective project management arrangement (including tight MOF oversight and five specialist taskforces) to implement the antievasion plan to restore tax discipline through: strengthened collection funds-of the largest debtors; a reorganized large taxpayer unit focused on the compliance of the largest revenue contributors; a strong auditenforcement and Request recovery of tax arrears-coordinated with the social security program to defeat pervasive evasion by high-wealth individuals and high income self-employed, including prosecution of the worst offenders; and a strengthened filing and payment control program.

Publish a detailed report by the ministry of finance in cooperation with the single payment authority on the structure and levels of compensation and the volume and dynamics of employment in the general government.

Adopt new Regulation of Statistical Obligations for the agencies participating in the Greek Statistical System.

$\begin{array}{ccc}\text { Request } & \text { Dec-10 } & \begin{array}{c}\text { Met with } \\ \text { delay }\end{array} \\ \text { Request } & \text { Dec-10 } & \begin{array}{c}\text { Met with } \\ \text { delay }\end{array}\end{array}$

Pass legislation to: (i) streamline the administrative tax dispute and judicial appeal processes; (ii) remove impediments to the exercise of core tax administration functions (e.g. centralized filing enforcement and debt collection, indirect audit methods, and tax returns processing); and (iii) introduce a more flexible human resource management system (including the acceleration of procedures for dismissals and of prosecution of cases of breach of duty).
Appointment of financial accounting officers in all line ministries and major general government entities (with the responsibility to ensure sound financial controls).

2nd rev Feb-11 $\begin{gathered}\text { Met with } \\ \text { delay }\end{gathered}$

2nd rev Mar-11 $\begin{gathered}\text { Met with } \\ \text { delay }\end{gathered}$ 
Table 3. Greece: Structural Conditionality (cont.)

\begin{tabular}{|c|c|c|c|}
\hline \multirow[t]{2}{*}{ Measures } & \multicolumn{3}{|c|}{ Date } \\
\hline & Set & Target & Status \\
\hline \multicolumn{4}{|l|}{ Prior actions and structural benchmarks } \\
\hline $\begin{array}{l}\text { Publish the medium-term budget strategy paper, laying out time-bound plans to address: (i) } \\
\text { restructuring plans for large and/or lossmaking state enterprises; (ii) the closure of } \\
\text { unnecessary public entities; (iii) tax reform; (iv) reforms ot public administration; (v) the public } \\
\text { wage bill; and (vi) military spending. }\end{array}$ & 2nd rev & Apr-11 & $\begin{array}{l}\text { Met with } \\
\text { delay }\end{array}$ \\
\hline $\begin{array}{l}\text { Articulate a strategic plan of medium-term revenue administration reforms to fight tax } \\
\text { evasion. }\end{array}$ & $3 r d$ rev & Jun-11 & $\begin{array}{l}\text { Met with } \\
\text { delay }\end{array}$ \\
\hline $\begin{array}{l}\text { Publish three consecutive months of consistent arrears and consolidated general government } \\
\text { fiscal reports (excluding small local governments). }\end{array}$ & 3rd rev & Jun-11 & $\begin{array}{l}\text { Met with } \\
\text { delay }\end{array}$ \\
\hline $\begin{array}{l}\text { Adopt the necessary changes to enact the plan to reform the general government personnel } \\
\text { system. }\end{array}$ & $3 r d$ rev & Jun-11 & $\begin{array}{l}\text { Met with } \\
\text { delay }\end{array}$ \\
\hline Parliament to approve medium-term budget strategy (MTFS). & 4th rev & PA & Met \\
\hline $\begin{array}{l}\text { Government to legislate key fiscal-structural reforms in an MTFS Implementation Bill (detailed } \\
\text { in Annex I). }\end{array}$ & 4th rev & PA & Met \\
\hline
\end{tabular}

Government to enact legislation in the context of MTFS implementation (phase II) to: (i) introduce pension adjustment bill stipulating freezes through 2015, introducing individual social security numbers, caps, means testing, and rationalizing benefits of pension funds; (ii) introduce single public pay scale bill, temporarily freeze automatic progression, and halve productivity allowance; and (iii) close 40 small public entities, merge 25 more small entities, and close an additional 10 large entities under line ministries and in the social security sector.

Government to achieve quantitative targets set under its anti-tax evasion plan.

4th rev

Dec-11

n.a.

Government to complete key actions to implement the various measures approved in the context of the first MTFS reform bill and anticipated in the second set of reforms bills (Annex I), including the reform of the public sector wage grid and the closure and/or merger of extrabudgetary funds.

Government to enact spending reductions (including pensions and earmarked spending and advanced removal of the heating fuel subsidy); revenue measures (including reducing PIT thresholds and reductions) as described in MEFP paragraph 6.

Parliament to approve a tax reform package, including [(i) a simplification of the code of Books and Records, (ii) the elimination of several tax exemptions and preferential regimes under the corporate income tax and the VAT; (iii) simplification of the VAT and property tax rate structures; and (iv) a more uniform treatment of individual capital income].

Government to undertake a thorough review of public expenditure programs to identify [3] percent of GDP in additional measures (including a 1 percent of GDP buffer of potential additional measures).

Government to meet newly introduced and more ambitious targets for audits and debt collection and the resolution of administrative appeals.

5th rev Dec-12 n.a.

\section{Competitiveness reforms}

Prepare a privatization plan for the divestment of state assets and enterprises with the aim to raise at least 1 billion euro a year during the period 2011-2013.

Table legislation to reform the system of collective bargaining, including to eliminate the automatic extension of sectoral agreements to those not represented in negotiations, and guarantee that firm level agreements take precedence over sectoral agreements without 
Table 3. Greece: Structural Conditionality (cont.)

\begin{tabular}{|c|c|c|c|}
\hline \multirow[t]{2}{*}{ Measures } & \multicolumn{3}{|c|}{ Date } \\
\hline & Set & Target & Status \\
\hline \multicolumn{4}{|l|}{ Prior actions and structural benchmarks } \\
\hline The Council of Ministers to adopt a comprehensive privatization plan through 2015. & 3rd rev & Jul-11 & $\begin{array}{l}\text { Met with } \\
\text { delay }\end{array}$ \\
\hline Parliament to approve privatization and real estate development strategy. & 4th rev & PA & Met \\
\hline $\begin{array}{l}\text { Government to legislatively establish a Privatization Agency (a private law vehicle into which } \\
\text { privatizable assets will be transferred to be sold). }\end{array}$ & 4th rev & PA & Met \\
\hline $\begin{array}{l}\text { Government to (i) shift a second group of assets into the privatization fund covering } \\
\text { transactions to be completed through end-2012 (Annex II); and (ii) appoint legal, technical, an }\end{array}$ & & PA & n.a. \\
\hline
\end{tabular}

financial advisors for 14 projects to be completed by end-2012.

Government to enact legislation to (i) allow worker representatives to negotiate both special and regular firm-level agreements; (ii) suspend the "favorability clause" in wage negotiations until at least 2015; and (iii) suspend until at least the end of 2014 the possibility to extend sectoral agreements to parties not represented in the negotiations.

Government to screen specific service sector legislation and repeal or modify unnecessary and outdated regulations to ensure full consistency with the new law liberalizing all professions and income-generating economic activities.

Government to enact legislation to (i) reduce the employers' share of social security contributions, including by rationalizing and consolidating small earmarked funds and broadening the base ; and (ii) improve the administration of security contribution collections, including by combining collection functions.

\section{Financial sector}

Establish the independent Financial Stability Fund (FSF) to preserve the financial sector's soundness and thus its capacity to support the Greek economy by providing equity support to banks as needed.

Enactment of $€ 25 \mathrm{bn}$ bond guarantee for bank liquidity

Jun-10

Met

1 st rev

PA

Met

Pass legislation to separate the core consignment activity from the commercial activities of the HCLF.

$\begin{array}{ccc}\text { 2nd rev } & \text { Mar-11 } & \begin{array}{c}\text { Met with } \\ \text { delay }\end{array} \\ \text { 3rd rev } & \text { Mar-11 } & \begin{array}{c}\text { Met with } \\ \text { delay }\end{array}\end{array}$

Government to put forward for legislative adoption a new tranche of government guarantees
for uncovered bank bonds. $\quad \begin{array}{lc}\text { Mrd rev } & \text { Met with } \\ \text { delay }\end{array}$

Commercial banks to submit medium-term funding plans to the ECB and the Bank of Greece. 3rd rev May-11 Met

Parliament to pass legislation revising the FSF operating framework (to address conditions for recapitalization) and revising the bank resolution framework (in particular, the deposit guarantee scheme, and the early intervention and bank liquidation frameworks).

4th rev 15-Sep-11 $\begin{gathered}\text { Met with } \\ \text { delay }\end{gathered}$

Government to enact legislation to address outstanding issues regarding the governance arrangements for financial oversight agencies, including (i) organizational arrangements for the Bank of Greece; (ii) the corporate governance arrangements for the HFSF; and (iii) the governance arrangements for the HDIGF.

Bank of Greece and FSF to complete a memorandum of understanding to further strengthen their cooperation (sharing of appropriate supervisory information). 


\section{References}

Aslund, Anders, April 3, 2013, "IMF shouldn't abandon austerity," Bloomberg, http://www.bloomberg.com/news/2013-04-02/imf-shouldn-t-abandon-austerity.html

Buiter, Willem, May 5, 2010, "Greek sovereign debt restructuring delayed but not avoided for long," Citigroup Economics Flash, www.willembuiter.com/greekflash.pdf

El-Erian, Mohamed, May 3, 2010, "Many more chapters left in the Greece drama," Financial Times (International), http://www.ft.com/intl/cms/s/0/32c5426e-56c0-11df-aa8900144feab49a.html\#axzz2RUTIPSPZ

European Central Bank, July 2011, "The European Stability Mechanism," Monthly Bulletin 07/2011, http://www.ecb.int/pub/pdf/mobu/mb201107en.pdf

European Commission, May 2010, "The Economic Adjustment Programme for Greece," DirectorateGeneral for Economic and Financial Affairs, Occasional Papers No. 61, http://ec.europa.eu/economy finance/publications/occasional paper/2010/pdf/ocp61 en.p df

Fernandez-Villaverde, Jesus, Luis Garicano and Tano Santos, March 2013, "Political credit cycles: The case of the euro zone," National Bureau of Economic Research, Working Paper 18899, www.nber.org/papers/w18899

Goodhart, Charles, May 8, 2010. Interview with MoneyControl, "IMF bailout not enough to cure Greek crisis, say experts," CNBC-TV18, http://www.moneycontrol.com/news/economy/imfbailout-not-enough-to-cure-greek-crisis-say-experts 456555-5.html

International Monetary Fund, 2011, "Review of the flexible credit line and precautionary credit line," IMF Policy Paper, http://www.imf.org/external/np/pp/eng/2011/110111.pdf

International Monetary Fund, 2012a, "2011 Review of Conditionality-Background Paper 1: Content and Application of Conditionality," IMF Policy Paper, http://www.imf.org/external/np/pp/eng/2012/061812.pdf

International Monetary Fund, 2012b, "Euro area policies-2012 Article IV Consultation," IMF Country Report No. 12/181, http://www.imf.org/external/pubs/ft/scr/2012/cr12181.pdf

International Monetary Fund, April 26, 2013, "Sovereign debt restructuring-Recent developments and implications for the Fund's legal and policy framework," IMF Policy Paper. http://www.imf.org/external/np/pp/eng/2013/042613.pdf

Kang, Joong Shik and Jay Shambaugh, April 2013, "Progress towards internal devaluation in the GIPS and the Baltics," Internal IMF unpublished document.

Kirkegaard, Jacob Funk, May 16, 2010, "A default by Greece: Why and When?" PIIE RealTime Economic Issues Watch, http://www.piie.com/blogs/realtime/?p=1574 
Lachman, Desmond, 2010, "Greece's Threat to the Euro" Review of European Economic Policy, Vol. 45 \#2, pgs. 93-95, March/April.

Mackenzie, James, January 14, 2010, "Eurogroup's Juncker says no need for Greece IMF aid,"

Reuters, http://www.reuters.com/article/2010/01/14/eu-juncker-greeceidUSPAB00809520100114

Moody's Investor Service, June 14, 2010, "Key drivers of Greece's downgrade to Ba1."

Mussa, Michael, 2010, "Beware of Greeks bearing debts," Peterson Institute for International Economics paper, http://www.iie.com/publications/papers/mussa201005.pdf

Münchau, Wolfgang, April 18, 2010, "Greece's bail-out only delays the inevitable," Financial Times (London), http://www.ft.com/cms/s/0/da5b9516-4b1f-11df-a7ff-00144feab49a.html

OECD, (forthcoming), "Greece: Reform of Social Welfare Programmes," OECD Public Governance Reviews, OECD Publishing.

Papaconstantinou, George, April 25, 2010, Press conference transcript, www.imf.org/external/np/tr/2010/tr042510.htm

Pisani-Ferry, Jean, André Sapir, and Guntram B. Wolff, July 19, 2011, "TSR External Study-An evaluation of IMF surveillance of the euro area," http://www.imf.org/external/np/pp/eng/2011/071911.pdf

Roubini, Nouriel, June 28, 2010, "Greece's best option is an orderly default," Financial Times, http://www.ft.com/intl/cms/s/0/a3874e80-82e8-11df-8b15-00144feabdc0.html

Sapir, André and Jean Pisani-Ferry, April 22, 2010, "Germany should share the blame for the Greek crisis," http://www.bruegel.org/blog/detail/article/264-germany-should-share-the-blamefor-the-greek-crisis/

Taylor, Edward, May 14, 2010, "Deutche Bank CEO Josef Ackerman seriously doubts Greece's ability to repay its debts," Reuters, http://www.nydailynews.com/news/money/deutsche-bank-ceojosef-ackerman-doubts-greece-ablity-repay-debts-article-1.445208

Tsibouris, George, Mark Horton, Mark Flanagan, and Wojciech Maliszewski, 2006, "Experience With Large Fiscal Adjustments," Occasional Paper No. 246, IMF, Washington D.C., www.imf.org/external/pubs/nft/op/246/op246.pdf

Vines, David, June 15, 2010, "How to rescue the EMU," VOX, Available via the Internet: http://www.voxeu.org/article/how-rescue-eurozone-lessons-southeast-asia

Wolf, Martin, May 4, 2010, "A bail-out for Greece is just the beginning," Financial Times (International), http://www.ft.com/intl/cms/s/0/de21becc-57af-11df-855b00144feab49a.html\#axzz2RUTIPSPZ

Zettelmeyer, Jeromin, Christoph Trebesch and Mitu Gulati, April 27, 2013, "The Greek debt restructuring: an autopsy," Unpublished (EBRD, University of Munich and Duke University). 


\section{Appendix I. Views of the Authorities}

The views of the Greek authorities on program outcomes and design were sought during a visit to Athens from March 20-22, 2013. Meetings were held with officials in both the current government and the government in office when the SBA was negotiated in 2010. Meetings were also held with representatives of the banking sector and the Bank of Greece. Views heard at the meetings are summarized below.

With regard to Fund involvement, the view expressed was that it would have been better if the crisis could have been resolved within the EU/euro zone, but neither the authorities nor the EC or ECB had the required program experience. The Fund's experience in crisis resolution made it a necessary part of the process. Another sentiment expressed was that the "4-3-3" deficit reduction program initially insisted on by the EC was too ambitious and reflected a legalistic approach to meeting the Maastricht Criteria and Excessive Deficit Procedure. Moreover, the initial interest rates on the loans from the euro partners were too high creating doubts about sustainability.

Officials noted that Greece itself and European partners were against debt restructuring at the outset because of concerns about domestic political costs, implications for social security funds, and contagion, but as time passed this possibility ripened. There were a number of false starts before a workable proposal emerged. The Deauville announcement had unexpectedly put restructuring back on the table and had severely unsettled markets just at a time that the program was showing some success and Greek spreads were beginning to decline. Later, the possibility of Greece exiting the euro became a public debate by the euro partners, a discussion that should have occurred behind closed doors.

The negotiations took place in a very short period of time. This had costs. There was insufficient time for political dialogue and consultation with people at the administrative level. This reduced buy-in for the program and led to local knowledge not being fully used to tailor conditionality to the specifics of Greece.

The common view was that no-one could have predicted the depth and length of the recession. However, officials acknowledged that the program's macroeconomic projections had risks to the downside that materialized in a context of political instability and deposit outflows. Also, in calculating the effects of tax measures, price and income elasticities were underestimated and this reduced the revenue yield. Data revisions that widened the 2009 fiscal deficit by 2 percentage points of GDP made the required fiscal adjustment even more demanding. Greater emphasis should have been placed on addressing deposit outflows and their effects and maintaining financing conditions consistent with the macroeconomic program. Financing constraints implied limits on the flexibility of targets, but this had led to a vicious circle whereby the deeper the recession, the greater the need for measures, and the deeper the recession.

Doubts were heard about the emphasis in the original program on raising taxes rather than reducing spending. On the one hand, taxes were relatively low and raising them was politically 
easier. However, the private sector had borne the brunt of the adjustment, while public sector employees continued to enjoy permanent employment. With hindsight, greater effort should also have been made at the beginning of the program to privatize state assets and to clamp down on prominent tax evaders.

Program implementation had started decisively, but markets became worried by social and political unrest and uncertainty about euro area policy. The data revisions affected sentiment and there were concerns about insufficient financing in 2013 and 2014 after the program ended. Some officials argued that the SBA should have been an EFF from the start. It was noted that an EFF had later been used for Ireland which had far less structural problems.

Limited ownership conspired against implementation. The political atmosphere in 2010 was not promising to secure support. Some argued that the government failed to take full advantage of its political capital and to explain the program to the public. The then government blamed the opposition for causing the crisis and did not seek its support. And the opposition contested the program and did not seek common ground. Many politicians even within the government attempted to distance themselves from the measures. The Fund sought to talk to the trade unions, but these attempts were not fruitful.

Consensus on the program has now improved with the coalition government. However, the crisis and the recession have had terrible consequences for Greece in terms of unemployment and have caused severe stress in society with extreme parties now gaining support.

Slippage in program implementation also reflected weak capacity. Officials recognized that they had underestimated the requirements of the program and overestimated Greece's administrative capacity to undertake reforms. When laws were changed, there was insufficient follow up to ensure implementation and results were not analyzed, measured, and tracked. The weakness in administration and management necessitated multi-layered and repeated reforms and ever-more detailed conditionality, particularly with regard to improving tax administration since this was critical to the success of the program. The intensive TA involvement by the EC Task Force and the Fund was welcomed by officials and was not considered to be intrusive given the deep assistance that Greece needed.

The Troika reflects three different institutions. This sometimes posed coordination problems: the Fund made decisions in a structured fashion, while decision-making in the Euro Zone spanned Heads of State and multiple agencies and was more fragmented. Officials observed that it took time for the Troika to gel as a unit, for example, in formulating a common macro view, but in general, dealing with the Troika was fairly smooth. The Troika partners listened to each other and were wellprepared. However, detailed conditionality increased the coordination challenge. There was also sometimes a lack of continuity in the Troika teams. All-in-all, this exacerbated uncertainty and reduced the possibility for early agreements. 